\title{
ECONOMIA POLITICA
}

\section{O OBJECTO DA ECONOMIA POLITICA}

\section{SUMMARIO}

I. Conveniencia em SE DETERminar COM EXACTIDÃO O OBJECTO DA ECONOMIA Politica.

II. DiVERgencia SOBRE ESTE PONTO ENTRE os ECONOMISTAS.

III. O OBJECTO DA ECONOMIA Politica E A INDUSTRIA, O TRABALHO, A ACTIVIDADE HUMANA?

IV. E' A ORDEM SOCIAL, O BEM ESTAR DO HOMEM OU DA COLLECTIVIDADE?

V. E' a RIQUeza? Conceito E nOÇÃo dE RIQUEZA.

VI. O objecto da Economia Politica é o ESTUDO DO VALOR OU DAS TROCAS.

VII. IMPUgnaÇÃo DESSA DOUTRINA POR LEROX BEAULIEU.

VIII. ImpUgnaÇÃo DA MESMa POR CICCONe.

IX. ImpUgnaÇão por A. Buylla.

$\mathrm{X}$. OUtRas obJEcÇões E CONClusÃo.

\section{$\mathbf{I}$}

1. $-E^{\prime}$ de capital importancia para o estudo de uma sciencia determinar-se-lhe com exactidão o objecto, de modo a excluirem-se della todos os elementos que lhe são estranhos.

Com esta delimitação da sua orbita, perde o estudo scientifico quantitativamente, a saber-em sua capaci- 
dade; ganha, porém, qualitativamente, isto é-quanto á sua clareza e precisão.

2. -Deve, tambem, lucrar quanto ao seu progresso. Sendo, com effeito, menos dilatada a esphera scientifica poderá, por isso, sobre ella exercer-se com maior intensidade a applicação mental.

Certamente, a quem tivesse de estudar omnes res scibiles ou a sciencia integral, não sobraria tempo nem vigor de espirito para aprofundadas e fecundas locubraç̃es, como áquelle que se dedicasse a um só departamento da encyclopedia das sciencias.

3.-O primeiro cuidado que temos quando é nosso fito o conhecimento geographico de um paiz, consiste em the discriminar as fronteiras, em determinar os limites que o separam dos paizes circumvisinhos. A processo analogo se apega o scientista que pretende iniciar um estudo novo. Esforça-se por assignalar precisamente a sua posição geographica no mappa das sciencias.

E' indispensavel para esse fim a exacta determinação do objecto da sciencia.

Com esta especialisação facilita-se o seu estudo.

$4-$ Em relação á Economia Politica é tanto mais necessario este trabalho preliminar, quanto é certo que, sobre ponto fundamental como este, não ha harmonia de conceitos entre os mais notaveis Economistas.

\section{II}

5.-Causa estranheza que não exista, até ao presente, uniformidade de vistas entre os autores de Economia Politica sobre o objecto desta sciencia. 
E', todavia, esta a verdade.

6. -Effectivamente, raros são os Economistas que tem traçado ao estudo da Economia Politica a justa esphera dentro da qual elle deve permanecer.

A generalidade dos escriptores, obedecendo a tendencias diversas e desprendidos de methodo logico, chegam a rezultados arbitrarios, destituidos de caracter scientifico.

Assim, quanto á esphera da Economia Politica:

a) Alguns a restringem em demasia; venientemente;

b) Outros, em maior numero, ampliam-na incon-

c) Outros, finalmente, a desvirtuam, dando-lhe differente objecto.

7.-Entre os autores que adoptam sobre o objecto da Economia Politica uma concepção restrictiva, limitar-nos-emos a mencionar alguns Economistas classicos.

8.-Para J. B. Say a Economia Politica outro objecto não tem a não ser «o estudo das leis geraes e naturaes do trabalho e da industria». (I)

Certamente, o estudo destas leis, uma vez que ellas influenciam sobre a producção e, conseguintemente, sobre as relações entre a ofterta e a procura, interessa a Economia Politica. Não é, porém, o seu objecto; não abrange-toda a sciencia economica.

Além disto, ha elementos economicos que não derivam do trabalho, pois não é elle o unico factor da producção. Com a mesma ou melhor plausibilidade poder-se-ia dizer que o estudo das leis geraes e naturaes do trabalho-é objecto da sciencia-do direito natural,

(I) J. B. SAy, Traité d'Economie Politique, Discours preliminaire. 
do direito publico, administrativo, civil, commercial ou industrial.

Logo, a concepção de J. B. Say, ao menos a enunciada na formula acima transcripta (2), pecca por demasiadamente restrictiva.

9. - Passemos á noção dada por Sismondi. Diz o eminente Economista suisso: «O bem estar physico do homem, emquanto póde ser considerado como obra do seu governo,- - tal é o objecto da Economia Politica». (3)

Este enunciado não resiste á mais simples analyse. Cada uma das suas palavras envolve um erro em sciencia.

Em primeiro lugar, não é acertado dizer-se que o objecto da Economia Politica seja-o bem estar physico. Não ha, por ventura cousas, direitos e serviços, com valor economico, que interessem o bem estar moral $e$ intellectual? Estas cousas, direitos e serviços deixam, por isso, de pertencer ao dominio da Economia Politica!?

Em segundo lugar: porquê «o bem estar-do homem»? Então, o que interessa o bem estar collectivo, o bem estar social (4), deixa de ter valôr, deixa de ser objecto da Economia Politica?

Prosegue Sismondi: «. emquanto póde ser considerado como obra do seu governo». Assim, so-

(2) De facto, como adiante se verá, o notavel Economista variou muito em seus escriptos, sobre ponto importante.

(3) Simonde de Sismondi, Principes d'Economie Polztique. Preface.

(4) Garnier, Traité d'Econ. Polit., corrige a formula de Sismondi e dá como fim final da Economia Politica-o bem estar e a moralidade da populaşão. Diz elle no n. 871: "A Economia Politica propõe-se, a final, a prosperidade, a abastança e o BEM ESTAR da população, emquanto esta prosperidade e este bem estar podem rezultar da remuneração do trabalho e da riqueza obtida, circulando, repartindo-se e sendo empregada da maneira a mais racional e a mais equitativa.» 
mente a acção official é que dá ao objecto o caracter de elemento economico!. Mas, tal noção é inadmissivel. Este conceito caberia antes á sciencia da administração. Um só exemplo:-a hygiene publica. Ella interessa o bem estar physico do homem e depende da acção do governo; não constitúe, entretanto, ninguem o dirá, objecto da sciencia economica.

10.--Um notavel economista allemão, Ch. H. Rau, dá como objecto da Economia Politica - os bens materiaes.

Eis como elle textualmente se exprime:

«Comprehende-se no haver (vermogen) de uma pessoa:

I. O seu direito a certos objectos materiaes (accepção subjectiva);

2. A somma dos bens externos que estão em seo poder (accepção subjectiva).

Nós não podemos dispôr livremente senão dos bens que fazem parte do nosso haver; mas ninguem póde passar sem os bens materiaes: por isso a producção, a acquisição e o consumo desses bens-é um dos assumptos mais geraes e mais importantes da vida do homem. O trabalho que tem por fim nos prover de bens materiaes (haver, fortuna) charna-se economia, e faz o objecto da sciencia da Economia Politica (Wirthschaftslehre, Oekonomie)». (5)

Certo, este trabalho é um elemento economico e, como tal, objecto da Economia Politica; não constitúe, porém, todo o objecto della. Ha outros, além deste, que se comprehendem na orbita dos estudos economicos.

(5) Ch. H. Rau, Trait. d'Econ. Polit., (trad. de Hemmeter) Bruxellas, I 839 , Introd. $\S 2$. 
O enunciado, portanto, sem ser erroneo, pecca por deficiente.

11. - Muito se approxima desta concepção a de Supino, para quem «as manifestações da actividade humana, guiada pela lei do minimo esforço, tendo por escopo a consecução e o uso dos meios necessarios á satisfação das necessidades, formam o campo de estudo da sciencia que se chama Economia Politica». (6)

A' esta noção, sobre a qual respigaremos adiante, applicam-se as mesmas observações criticas a que se presta a doutrina de Rau.

12. - Ampliam a esphera da Economia Politica, entre outros escriptores, Quesnay, J. B. Say, Adam Smith e Storch.

Examinemos, em breve analyse, o conceito scientifico adoptado nas obras de cada um desses illustres tratadistas:

13.-Quesnay dá como objecto da Economia Politica- «todo o vasto campo das relações sociaes da humanidade, em todas as suas partes, physicas e moraes». (7)

Como se vê, é este o objecto da Sociologia, que é uma sciencia geral; e não da Economia Politica, que é um ramo daquella sciencia e uma sciencia especial.

A concepção de Quesnay abrange todo o genero, e não sómente a especie. E', por isso, defeituosa.

14.-J. B. Say, em contradicção comsigo mesmo, depois de haver restringido, como acima vimos, a

(6) Supino, Principi di Econ. Polit., Napol. I904, Introd. pag. 2.

(7) Quesnay, Droit Naturel; MACleod, Elem. of Polit. Econ., n. 5. 
Economia Politica ao estudo das-leis geraes e naturaes do trabalho, não duvida dizer que: «a Economia Politica abrange o systema social todo inteiro », por isso que-«é um ramo da historia natural do homem». (8)

A este enunciado applica-se, mutatis mutandis, a mesma critica que acabamos de fazer á opinião de Quesnay.

15. - No conceito de A. Smith, o fim da Economia Politica é «enriquecer o povo e o soberano»: e o seu objecto; «o estudo das leis naturaes que determinam a prosperidade das nações, isto é a sua civilisação e riqueza». (9)

$\mathrm{O}$ estudo que tem por objecto a riqueza do povo e do soberano, considerado um ou o outro em seo caracter de pessoa politica - é a Sciencia das Finanças, e não a Economia Politica.

Quanto á civilisação de um pôvo, comprehende ella uma complexidade de elementos estranhos, em grande parte, ao objecto da sciencia economica.

16. - A concepção de Storch é analoga á de Smith. Elle a exprime quasi nos mesmos termos, e accrescenta: "a investigação das leis ou relações harmonicas dos interesses». (10)

Quanto á esta ultima parte,-quaes os interesses a que se refere o economista? Não ha, com effeito, expressão mais vaga. Se o autor allude sómente a

(8) J. B. SAY, Cours complet d'Economie Politique. Introd.

(9) AD. Sмrтн, Au inquery into the nature and causes of the wealt of nations, Liv. IV Introd.

Não nos parece fundada a observação de WALRAs, (Elem. d'Econ. Polit. pure, pag. 6), que pretende que SMITH define a Economia Politica pelas suas applicações, e não pelo seu objecto.

(ro) Storch, Cours d'Econ. Polit., vol. I, Introd. gen. 
interesses materiaes, à sua concepção pecca por acanhada; se inclúe os interesses moraes e intellectuaes, neste caso, a sua concepção é erronea; porquê ha interesses dessa natureza que escapam completamente á esphera dos estudos economicos. (I I)

$\mathrm{Ha}$, tambem, interesses materiaes estranhos ás preoccupações dos economistas.

Entre uns e outros, basta lembrarmos os intevesses que se prendem á instrucção publica, á hygiene, á policia etc., cujo estudo, entretanto, não se inclúe na orbita da Economia Politica.

17.-Entre os autores que disvirtuam o objecto da Economia Politica, nomearemos, exemplificativamente, ainda J. B. Say, e com elle Gide, Oliveira Martins, Beauregard e a corrente dos economistas classicos, que dão como objecto da Economia Politicaa riqueza.

Observemos no exame dessas opiniões o methodo analytico.

18. - Empregando uma formula que fez carreira e é hoje adoptada pela generalidade dos economistas, disse J. B. Say que «a Economia Politica tem por

(I I) Que a expressão-interesses, foi pelo eminente economista empregada em accepção ampla não padece duvida, em vista do seguinte trecho em que elle desenvolve analyticamente o mesmo conceito da sua definição: «A Sciencia social, tem dois objectos distinctos:

I. Ella tracta de investigar as leis aturaes que presidem ao desenvolvimento da especie humana e que lhe regulam a marcha; ella mostra como o homem social consegue satisfazer a todas as suas necessidades, quer physicas quer moraes, e quer naturaes quer facticias; como as riquezas, as artes, as luzes, as virtudes sociaes nascem, augmentam e se distribuem: numa palavia esta sciencia nos desvenda o mecanismo natural que produz a prosperidade das nações. Quando ella tem este objecto, ella se chama Economia Politica, sciencia que se divide em duas doutrinas: a da riqueza nacional, e a da civilisasão.» (STORCH, obr. cit. Disc. prelim.) 
objecto-a producção, a distribuição e o consumo da riqueza». (I 2 )

Ora, esta proposição não é rigorosamente verdadeira. Não é licito, pois, acceital-a como scientifica.

De facto, pode-se conceber a existencia daquelles tres phenomenos, fóra da orbita das leis economicas:

Assim, as produç̧ões agricola, industrial, artistica, litteraria e scientifica operam-se segundo leis technicas peculiares á agricultura, á industria, e ao estudo das artes, das lettras e das sciencias; e não pela applicação das leis da Economia Politica.

Do mesmo modo, póde se conceber a distribuição da riqueza por intervenção da autoridade e,"portanto, sem a applicação das leis economicas. Outra não é a aspiração do socialismo; e foi este o systema vigente no Paraguay, durante o periodo das Missões jesuiticas, e nas altas terras da Escossia. (I 3 )

E o consumo, não se póde, accaso, realisar sem a applicação dos principios da Economia Politica? Imagine-se, por exemplo, a destruição de riquezas por accidentes naturaes - $\mathrm{O}$ incendio, a inundação, a geada, a peste, terremotos, naufragios etc.

19.-Segundo Gide. mas preferimos reproduzir textualmente as suas palavras. Diz elle: "Os mesmos objectos podem ser encarados sob pontos de vista distinctos... e convém discriminar os objectivos do moralista, do jurisconsulto e do economista. Ora, isto é facil. Fazer o seu dever, exercer o seu direito, satis-

(I2) O sub-titulo do seu Traité d'Economie Politique, é o seguinte: "ou Simple exposition de la manière dont se FORMENT, se DISTRIBUENT et se CONSOMMENT les RICHESSES.»

(13) H. D. MACLEOD, Elem. of Polit. Econ., vol. I, n. 28. 
fazer as suas necessidades-constituem tres fins, assaz differentes, da actividade humana.» (14)

Este conceito é deficiente, até na forma.

O objecto da Economia Politica não é tão restricto por um lado, nem tão amplo por outro. Ha necessidades humanas para cuja satisfação a Economia Politica não concorre:-as de ordem moral, por exemplo. Assim tambem ella estuda outros objectos que não constituem necessidades humanas.

Nem se nos opponha que estamos restringindo arbitrariamente a noção desse escriptor, com o lhe darmos um sentido material. Esta intelligencia rezulta das suas proprias expressões; pois elle accrescenta, tirando a conclusão do que expõe: «Digamos, portanto, que a Economia Politica tem por objecto as relações dos homens convivendo em sociedade,-quando taes relações tendem á satisfação das suas necessidades materiaes e ao desenvolvimento do seu bem estar». (I 5)

\section{III}

20.-No Programma de Ensino da Faculdade de Direito do Rio de Janeiro, apresentado para o curso de 1903 pelos Drs. Serzedello Corrêa e Didimo da Veiga lê-se o seguinte, sob o titulo-- Objecto e fim da Economia Politica: "A idéa fundamental da Economia Politica não é a de riqueza, a de valor, a de capital ou a de trabalho;-é a de industria».

Enuncia-se do mesmo modo o Dr. Silvio Romero.

Estes nossos illustres compatriotas seguiram neste ponto a doutrina de Coquelin e de outros Economistas, aos quaes adiante nos referiremos.

(14) Charles Gide, Princ. d'Econ. Polit., not. génér.

(I5) Charles Gide, obr. e lug. citados. 
21.--A noção de industria é complexa, por isso que ella abrange todos os tres classicos factores da producção, a saber-os agentes naturaes, o capital e o trabalho. Entretanto, como, no trecho citado, vem ella opposta a capital e a trabalho, assim como a riqueza e a valor, devemos entender que essa expressão foi empregada ahi em sentido restricto, que exclúa aquellas outras idéas.

Ora, neste caso, não contem uma verdade o conceito enunciado pelos illustres economistas patrios.

Com effeito, neste sentido restricto, a industria não interessa senão indirectamente ao estudo da Economia Politica; interessa, antes, como dizem Leroy Beaulieu e outros escriptores, á technologia. (16)

22. - Para o Economista a industria não é estudada senão como um factor de producção, portanto pelos seos rezultados; e sob este aspecto a sua importancia não sobrepuja á do capital e á do trabalho; sem os quaes não se concebe industria.

Se fosse possivel abstrahir-se da industria o seu objectivo, que é o augmento da riqueza, a producção para a permuta do producto, ella deixaria de interessar á Economia Politica (I 7). Ao contrario, a riqueza proveniente de outra fonte que não seja a industria, da natureza, por exemplo; ou o valor produzido pelo trabalho, ou pela renda do capital: são phenomenos que interessam a Economia Politica.

(16) Leroy Beaulieu, Trait. d'Econ. Polit., tom. I, pag. I5; J. B. SAy, Trait. d'Econ. Polit., disc. prelim.

(I 7) Esta hypothese é perfeitamente admissivel. Concebe-se, com effeito, a possibilidade de producção industrial não destinada a ser vendida. Para ser consumida, por exemplo, pelo proprio productor e sua familia, ou no interesse do Estado, sendo industria official. Ou ainda, á que tivesse fito exclusivamente bumanitario, ou scientifico, ou artistico. Em que tal industria, formal ou substancialmente considerada, affectaria a riqueza social? Como engendraria valor? Em que interessaria as leis economicas? 
Como affirmar-se, portanto, que a industria, com exclusão da riqueza, do valor, do capital e do trabalho -é a idéa fundamental da Economia Politica?!

Não vai tão longe o proprio Coquelin. (I8)

23. -Além disso, se a industria é um factor da producção, em que ella interessa á distribuição e ao consumo da riqueza? E pretenderão os distinctos lentes da Faculdade de Direito do Rio excluir do dominio da Economia Politica, ou mesmo dentro delle collocar em plano secundario, - os phenomenos da distribuição, e do consumo? Parecer-lhes-ão alheios a esta sciencia ou de somenos importancia assumptos como estes - a propriedade, a renda, a moeda, o credito, as permutas, o salario, as reservas, para não fallarmos do capital, do trabalho, da riqueza e das leis do valor?!

24.-Não é licito classificar-se Michel Chevalier entre os adeptos da escola que considera a industria como o objecto da Economia Politica, nem mesmo como a idéa fundamental desta sciencia.

Não somente as expressões por elle empregadas não autorizam aquella illação (19), como, tambem,

(I8) E' digno de consulta sobre este ponto o importante artigo de Ch. Coquelin, no seu Dictionnaire d'Econ. Polit, verb. «Economie Politique», seç̧ão IV. Ibi: "Definindo e caracterisando, no que precede, a sciencia economica, temos fallado incessantemente da industria e das leis geraes que a regem. E' para notar-se que nisto nós nos temos afastado, senão no fundo, ao menos na fórma, das definições geralmente acceitas e que se referem todas, mais ou menos, não á industria, porém á riqueza que a industria produz. Qual destas duas fórmulas é a mais acertada? E' o que convém examinar.

Em nosso conceito, não teem razão os que pretendem que é a riqueza - objecto da Economia Politica; quando, na realidade, é o trabalho humano, a industriæ humana, fonte das riquezas, que faz o objecto das investigações economicas. Fica, entendido, comtudo, que não temos, de modo algum, enunciando-nos por este modo, a intenção de mudar as bases da sciencia que, ao contrario, acceitamos taes quaes existem; o que, tão sómente, pretendemos estabelecer, é que, nos proprios trabalhos dos Economistas, fundadores da sciencia, não é na realidade a riqueza, mas a industria humana, que está constantemente em jogo.

(i9) Michel Chevalier, Cours d'Econ. Polit., vol. I, prem. disc.: «O mais bello florão da economia politica, é a industria.» Ora! - o mais bello 
porque em seu discurso tem o vocabulo-industria uma accepção mais ampla, comprehensiva egualmente da idéa de trabalho. (20)

25. - A concepção de Coquelin não deixa, entretanto, de ser compartilhada por alguns outros economistas; todos, porém, dão ao vocabulo industria um sentido philosophico, mais amplo que o de trabalho e comprehensivo deste.

26. - Assim, A. Jourdan, seguindo a lição de J. B. Say, (V n. 8 retro) considera a Economia Politica «a sciencia da industria humana», mas accrescentou «ella investiga os meios de tornar fecundo o trabalho humano». (2 I)

27.-No mesmo sentido, com muita subtileza de forma, pronuncia-se Moreno Villena. «O objecto da Economia Politica, diz elle, não é a riqueza, mas os meios de a obter; portanto,- $a$ industria. A riqueza, quer provenha da natureza, quer da actividade e do trabalho humano, - uma vez obtida, não constitúe objecto de estudo. (22)

florão! Foi certamente este abuso de expressões tropologicas, destituidas da precisão indispensavel á linguagem scientifica o que suggerio a Saint Marc Girardin, e não a Thiers, como se tem escripto, o labéo de litteratura enfado$n h a$, atirado á sciencia economica.

(20) Michel Chevalier, obr. e lug. cit.: "Escolho propositalmente aqui a relha do arado como o emblema da industria, para mostrar que della não separo a agricultura. A industria é o trabalbo material sob todas as suas fórmas. Ella é agricola, é manufactureira, é commercial."

Não se nos opponha que tambem foi esta a accepção dada á palavraindustria, pelos illustres cathedraticos da Faculdade Livre do Rio de Janeiro.

A simples leitura do trecho respectivo no programma a que alluaimos está patenteando que elles se referem á industria em opposição a trabalho; pois dizem textualmente: "a idéa fundamental da Economia Pclitica não $\dot{e} a$ de trabalho. MAS a de industria.» cap. II, pag. 6 .

(21) Altred Jourdan, Cours analyptique d'Econ. Polit., 2." ed., (22) P. Moreno Villena, Tratado de Econ. Polit. Madrid, 1903, $7 .^{\circ}$ ed., pag. 19. 
28. - E tambem Luiz M. Pastor, para quem o objecto da sciencia economica se reduz «a investigar as leis que regem a actividade humana em suas manifestações na producção, circulação e consumo». (23)

29.-Usando, embora, de formula diversa, approxima-se em substancia desta concepção Aprigio Guimarães, quando enxerga o objecto da Economia Politica « no trabalho, sob o ponto de vista do individuo e da sociedade; ou no individuo e na sociedade, sob o ponto de vista do trabalho». (24)

30. - Mais generica ainda é a expressão empregada por Constantini, cuja doutrina se approxima da de Pastor; pois, em seu conceito, a Economia Politica estuda «os phenomenos resultantes da actividade que os homens applicam para se procurarem os objectos de que necessitam e que a natureza lhes não dá gratuitamente». Portanto, conclúe esse escriptor: o objecto da Economia Politica não é a riqueza, mas a actividade humana. (25)

Quasi nos mesmos termos se enuncia Graziani. (26)

31.-Segundo Villey, «a sciencia economica. tem por objecto o estudo do desdobramento das actividades individuaes que constituem o movimento social». (27)

Este autor oppõe-se á definição «sciencia das riquezas», porque ella faz perder de vista que a riqueza

(23) Luiz M. Pastor, Leç. de Econ. Polit., Leç. X, pag. 147, Madrid, 1868 .

(24) Aprigio Guimarães, Estudos de Econ. Polit., Part. III, pag. 75.

(25) E. Constantini, Man. di Econ. Polit. Introd. Milão, I903.

(26) A. Graziani, Instit. di Econ. Polit. Introd. Cap. I.

No mesmo sentido, R. Estoublon, Cours d'Econ. Polit. Argel, I904. Ibi : «... a actividade humana applicada à satisfação das necessidades physicas, intellectuaes e moraes.»

(27) Ed. Villey, Princ. d'Econ. Polit. Introd. Cap. I. 
não é um fim, mas um meio; pois os productos são feitos para os homens, e não os homens para os productos.

32. - Marshall, o eminente economista britanico tem a seguinte concepção: «A Economia Politica, ou as Economias é um estudo do genero humano nos negocios ordinarios da vida (in the ordinary business of life). E', ao mesmo tempo, o estudo da riqueza e uma grande parte do estudo do homem. (28)

33. - Tem muita analogia com o conceito de Marshall o do economista norte-americano Davenport, que propõe as tres formulas seguintes para a definição do objecto da Economia Politica:

— «A investigação do modo pelo qual os homens pensam e agem nos negocios da vida; ou

-O estudo da actividade humana em relação com as cousas compradas e vendidas; ou melhor

-A sciencia que tracta dos homens em sua actividade commercial e industrial, sob o ponto de vista dos mercados e dos valores». (29)

34.-Dentre os economistas hespanhoes, accompanha em fundo a mesma doutrina Carreras y Gonzales, para quem o objecto da sciencia economica é «a actividade humana, exercida sobre todos os objectos do universo». (30)

35.--Não destoam da doutrina que temos exposto as opiniōes de dois emeritos economistas alle-

(28) A. Marshall, Princ. of Economics. Cap. I. Introd. § I.* Londres, 1898 .

(29) H. J. Davenport, Polit. Economy, cap I, n. 4. Chicago, 1897.

(30) M. Carreras y Gonzales, Trad.didatico de Econ. Polit. Introd. 
mães. Para Schulze-Delitzch, o denodado propugnador da philantropica idéa das associações de mutualidade, o objecto da Economia Politica são - «as leis naturaes que regem todas as manifestações da actividade humana e as condições da nossa existencia na ordem economica e commercial». (3 I)

Segundo Schmoller, aquelle objecto consiste na «actividade social applicada á producção da riqueza». (32)

36.-Vejamos agora a noção acceita por Leroy Beaulieu. Resulta da definição por elle proposta e recommendada como «beaucoup plus scientifique», muito mais scientifica que a generalidade das que estão em curso.

Eil-a; «A Economia Politica é a sciencia que investiga as leis geraes determinadoras da actividade e da efficacia dos esforços humanos para a producção e o gozo dos differentes bens que a natureza não concede gratuita e espontaneamente ao homem». (33)

37. - Dos conceitos que acima ficam registrados, os de Marshall e de Davenport não nos parecem substancialmente erroneos; ao contrario, com pequena modificação na forma do seu enunciado, não ficariam distantes da noção que nós temos como a verdadeira sobre este assumpto, e que havemos de expôr adiante desenvolvidamente, quando nos occuparmos da doutrina de Macleod.

Quanto aos demais, diremos tão sómente, por agora, que não consideramos como constitutiva do objecto da Economia Politica ou a sua idéa funda-

(3 I) Schulze-Delitzsch, Cours d'Econ. Polit. Introd., vol. I.

(32) G. Schmoller, Princ. d'Econ. Polit., vol. I, Introd. (traduc. de G. Platon) Paris, I 905 .

(33) P. Leroy Beaulieu, Traité d'Econ. Polit., vol. I, Part. I, Cap. I, pag. II. 
mental -a industria, nem tão pouco-o trabalho, e nem ainda a idéa mais generica da-actividade humana applicada á producção, ou o homem agindo com fito de lucro; por isso que, como pretendemos demonstrar nalgumas paginas adiante,-não sómente podem-se conceber phenomenos economicos sem directa dependencia da industria, do trabalho ou da actividade do homem; como tambem a intervenção de qualquer destes tres factores habituaes de producção, ou de todos elles conjunctamente, sem, todavia, o apparecimento de phenomenos que interessem a economia social.

\section{IV}

38. - Varios Economistas, filiados, em geral, á escola socialista, dão por objecto á Economia Politica -o estudo da ordem social, ou o bem-estar individual ou collectivo, ou a felicidade do homem ou da sociedade, ou qualquer outro analogo a algum destes.

$\mathrm{Na}$ observancia do mesmo methodo que até ao presente vimos seguindo, passarenıs a reproduzir as proprias fórmulas enunciadas por esses autores, e commentaremos com breve reflexão a doutrina de cada um delles.

Para que seja scientificamente verdadeira uma noção, faz-se indispensavel que ella se revista de fórma tão exacta, tão precisa que se applique exclusivamente ao objecto que tem por fim designar, e tambem que comprehenda de modo completo esse objecto.

Obedecendo a este criterio logico, vejamos como se exprimem os diversos sectarios da doutrina acima indicada em seus traços geraes.

39. - Piernas Hurtado considera como objecto da Economia Politica o estudo dos « . meios ma- 
teriaes que as necessidades da vida humana reclamam.» (34)

Ha necessidades que a vida humana reclama, e que se satisfazem por meios materiaes; mas que, nem por isso, são objecto pertinente ao estudo da Economia Politica, se bem que interessem de perto a sciencia da administração. Exemplo: todo o serviço da hygiene publica.

Por outro lado, ha interesses que não affectam propriamente á vida humana, mas tão sómente ao conforto da existencia, ao progresso e desenvolvimento da sociedade, e que não deixam, todavia, de se comprehender dentro da orbita dos estudos economicos.

40.-A primeira parte das reflexões que acabam de ser feitas são applicaveis á refutação da doutrina do economista flamengo Pierson, para quem o objecto da Economia Politica outro não é a não ser «o bem estar material dos homens.» (35)

41.-Ampliando esta concepção pretende Saralegui y Medina que tal objecto consiste na investigação das leis civis de cujo conhecimento se deduzem os principios mais convenientes á felicidade do homem e das sociedades.» (36)

Se este escriptor houvesse dicto - prosperidade,em vez de-felicidade-, não teria ficado tão distante da noção verdadeira; ainda assim, porém, mesmo esta expressão nos pareceria excessivamente ampla. Quanto

(34) J. Piernas Hurtado, Princ. element. de la Ciencia Economica. Introd., secc. III, 2. ${ }^{a}$ edic. Madrid, 1903 .

(35) N. G. Pierson, Tratt. di Econ. Polit. (vertido do hollandez para o italiano por E. MALAGolI), vol. I, § I.' Roma, I905.

(36) Saralegui y Medina, Trat. de Econ. Polit. Secc. Prim., cap. I, parte III, 3. ${ }^{\mathrm{a}}$ edic. Ferrol, 189I. 
mais a de felicidade, comprehensiva, como é manifesto, de elemento moral heterogeneo ás preoccupações do Economista?

42. - A noção adoptada por Bodevelles é antes applicavel ao direito industrial, ao direito commercial e mesmo ao civil que á sciencia economica.

Diz, com effeito, este autor: «A Economia Politica é a sciencia-das convenções ou leis positivas que regulam as relações que engendram entre os homens os esforços por elles empregados para a satisfação de uma parte das suas necessidades e dos seus desejos.» (37)

43. - Identica em substancia, se bem que differente na forma, é o conceito de E. D'Eichthal. Para elle, a Economia Politica é estranha aos processos technicos da producção da riqueza, e não se occupa senão com a «influencia dos moveis e das forças, que o arranjo social estimula ou contem, regula e coordena; e com as condições nas quaes estes moveis e estas forças agem, desenvolvem-se ou se paralysam pelas relações legaes ou costumeiras estabelecidas entre homens.» (38)

Este escriptor liga pouca importancia ás noções e definições e a toda a materia do capitulo denominado-generalidades. «Eu devera dizer, escreve elle, - banalidades; mas, que fazer? Forçoso é remontar em poucas palavras aos principios elementares.»

44.-Nas mesmas idéas, com a vantagem de menos prolixo, labuta Funck-Brentano, em cuja phrase

(37) Ch. Bodevelles, Princ. d'Econ. Polit. Notions Générales, cap. I. Paris, 1905 .

(38) Eugkine d'Eichthal, La Formation des richesses, etc. Parte I, liv. I, cap. I. Paris, I906. 
a Economia Politica «. .é a sciencia das relações que se estabelecem entre os homens em vista da satisfação das suas necessidades.» (39)

45. - Para A. Coste, sectario da escola positivista, o objecto da Economia Politica é o estudo das funcções economicas do organismo social, em sua acção harmonica com as funcções tutoriaes, civicas e doutrinaes.

Como se vê, deste enunciado, que é a condensação em poucas palavras de algumas paginas daquelle escriptor, (40) transparece a preoccupação sectarista que consiste em negar aos estudos economicos os fóros de sciencia autonoma dentro da vasta esphera da sociologia.

Pouco se affasta desta noção a de G. Greef, que considera a Economia Politica «a parte da sciencia social que tem por objecto o estudo das condições e das leis da vida de nutrição das sociedades.» (4 I)

46. - Segundo Cauwès, a Economia Politica é «a sciencia que tem por objecto as leis de utilidade applicaveis ao trabalho da sociedade, e por fim o bem estar individual assim como a prosperidade colectiva, mediante uma equitativa distribuição dos serviços e das riquezas.» (42)

Cumpre observar, accrescenta esse autor, accentuando o seu fito socialista, que esta definição colloca o homem no primeiro plano e as riquezas no segundo,

(39) Th. Funck-Brentano, Nouv. Préc. d'Econ. Polit., cap. II. Paris, 1887 .

(40) Adolphe Coste, Nounel Exposé d'Econ. Polit., cap. I, § 2. pags. 4 a 12 . Paris, 1889 .

(4I) G. DE GREEF, La Sociologie Economique, cap. I, n. I.

(42) P. CAuwts, Cours d'Econ. Polit., vol. I. Introd., § I. ${ }^{\circ}$ n. 7, 2." ed. Paris; $188 \mathrm{r}$.

A doutrina de CaUwès é acceita e reproduzida por P. Rambaud, Resumé d'Econ. Polit., cap. I, $\S \mathrm{I}^{\circ}$ 
e que assignala á Economia Politica um fim pratico. Por ahi ella differe profundamente da definição a mais usual a de J. B. Say, que se tornoù popular e segundo a qual a idéa dominante é a das riquezas.

47.-No mesmo sentido já doutrinou Passy: «Não é a riqueza ou, para empregar uma expressão mais lata, ao bem-estar que se applicam as investigações daquelles que cultivam a Sciencia Economica; é ao homem, agente e fim da riqueza e do bemestar. (43)

48. - Pouco diversa de algumas das precedentes é a opinião de Carey, segundo a qual, o objecto da Economia Politica cifra-se ao estudo das leis e dos phenomenos rezultantes do incentivo do genero humano consistente na sua conservação e progresso. (44)

49. - Ainda no mesmo sentido enuncía-se Scialoja, quando diz que a Economia Politica « .descreve as manifestações organicas da sociedade, que asseguram a sua conservação. (45)

50.-E tambem, na mesma ordem de idéas, ainda que com diversidade de fórma, A. W. Flux, lente cathedratico de Economia na Universidade de Montreal. Segundo a sua doutrina, a Economia Politica estuda «a organisação complexa das sociedades, as origens das suas riquezas, as partilhas pretendidas pelos seus membros e as remunerações dos serviços individuaes resultantes das occupações livremente exercidas sob o estimulo da recompensa desejavel.» (46)

(43) Fred Passy, Lec. d'Econ. Polit. Disc. Prelim.

(44) Carev, Princ. of Econ. Phil. Introd.

(45) A. Scialoja, Princ. di Econ. Polit. Disc. prelim.

(46) A. W. Flux, Economic Principles, cap. I. Introd. Londres, 1904. 
51.-Analoga enumeração se encontra n'outra obra americana, a de Rogers Seager, que considera a Economia Politica ou as Economicas como- «a sciencia social que tracta das necessidades humanas e dos bens (goods), isto é, das vantagens e dos serviços, (commodities and services) dos quaes dependem a satisfação das suas necessidades.» (47)

52.-Mais ou menos nas mesmas aguas navega Charles Perin, em cujo conceito a Economia Politica se interessa pela « .ordem material, a saber-a ordem na qual o homem exerce a sua actividade sobre as cousas do mundo exterior para dellas tirar a sua subsistencia.» (48)

Em sentido approximado, já havia dito A. Foy que - « .assignalar as causas que podem trazer a ampla satisfação das necessidades materiaes-tal é o objecto e tal é o fim da Economia Politica.» (49)

53. - Para Rodrigues de Freitas, a Economia Politica-estuda as leis que regem o organismo social e os principios a que obedecem a producção, a circulação, a distribuição e o consumo. (50)

Consoante com a mesma concepção, A. Buylla encherga o objecto da sciencia economica no estudo da «ordem constituida pelas relações do homem com a natureza e com os seus semelhantes para obter e applicar o meio adequado á satisfação das necessidades humano-corporaes.» (5 I)

(47) H. Rogers Seager, Introduction to Economics, cap. I, § I.“ Nova York, 1904.

(48) Ch. Perin, Prem. Princ. d'Econ. Polit, cap. I. Prelim. Paris, I 905.

(49) Alph. Fov, Essai sur les princ. de l'Econ. Polit., vol. I. Introd.

(50) J. J. Rodrigues De Freitas, Princ. de Econ. Polit., cap. I. Introd., pag. 10. Porto, sem data.

(5 I) Adolpho A. Bưlla, Economia, parte I, § 6. Madrid, 1894. 
54. - Para enfeixar esta já longa enumeração daremos agora as opiniões, analogas em fundo mas com alguma novidade na fórma, de tres Economistas filiados á escola socialista, a saber Laveleye, Blanqui e Karl Marx, aquelle belga, allemão este, e o segundo francez.

Laveleye, que contesta a existencia de leis naturaes em Economia Politica, e para quem esta sciencia, ou melhor este estudo, é apenas «affaire de législation», dá-lhe como objectivo «tornar a abastança tão geral quanto possivel.» (52)

Blanqui affirma um pensamento muito analogo, quando pretende que aquelle objectivo visa a «chamar - maior numero possivel de homens á partilha, dos beneficios da civilisação.» (53)

Finalmente Karl Marx, com algum fél, denomina a Economia Politica «a sciencia das miserias das classes populares.» (54)

\section{$\mathbf{V}$}

55. - Para Beauregard, o objecto da Economia Politica -é o estudo da riqueza. (55)

Neste conceito não está isolado o eximio cathedratico da Faculdade de Direito de Paris.

Ao contrario, caminha com elle a corrente dos economistas antigos e modernos; ou, mais exactamente, é elle que acompanha a mencionada corrente.

(52) Laveleye, Elêm. d'Econ. Polit., liv. I, cap. I, § r.“

(53) Blanqui, Hist. de l'Econ. Polit. Introd.

(54) Karl Marx, Le Capital. Pref. trad. por J. Roy.

(55) P. Beauregard, Eléments d'Econ. Polit. Introd. Ibi: «Diz-se geralmente que a Economia Politica é a sciencia da riqueza. Esta formula é exacta; e se ella não satisfaz as condições d'uma boa definição, offerece, todavia, na sua coucisão, um ponto de partida excellente para aquelle que queira formar uma idéa geral do objecto da sciencia economica.» 
56.-Assim, Cherbuliez (56) e Courcelle Seneuil (57) adoptam com pouca differença a formula, que já mencionamos, de J. B. Say, a saber que a producção, a circulação e o consumo, ou a producção, a circulação e a distribuição da riqueza, constituem o objecto da sciencia economica.

57 - Baudrillart, procurando com o seu ecclectismo satisfazer a todos os paladares, diz que a Economia Politica é sciencia que estuda «a producção, a distribuição e o consumo da riqueza»; mas logo accrescenta: «ou as leis que presidem ao trabalho e á permuta.» (58)

58. - Algum tanto approximadas destas são as idéas e até as expressões de Victor Deheurle (59), para quem a Economia Politica é o ramo da Economia Social que estuda especialmente--«como a utilidade material ou riqueza se produz, se distribúe e se consome»; e as de A. Liesse, segundo o qual, aquella sciencia- - «estuda as leis que presidem ao augmento e á diminuição da riqueza.» (6o)

59. - Jules Rambaud denomina a Economia Politica一 «a sciencia da riqueza»; e neste ponto tem elle a seu lado grande numero de escriptores (6I), por

(56) Cherbuliez, Précis de la Science Economique, vol. I. Introd. secç. $\mathbf{I}$.

(57) Courcelle Seneuil, Traité d'Econ. Polit., vol. I. Introd.,

(58) Baudrillart, Manuel d'Econ. Polit, cap. II.

(59) V. Deheurle, Nouveau Traité d'Econ. Polit., cap. I, pag. 2.

(60) André Liesse, Lesons d'Econ. Polit., prem. leç., pag. I 2. Reproduzimos, sem lhe darmos o nosso assentimento, a seguinte noção de riqueza dada por esse economista (ibidem pag. 8): "Chamam-se, em Economia Politica, riquezas-todas as cousas: a) materiaes, b) uteis, e c) apropriadas.» Mostraremos adiante a falsidade deste conceito. Por agora limitar-nos-emos a propôr a seginte questão: as apolices da divida publica, ou o direito a rendas ou a quaesquer pagamentos ou producção futuras,-são cousas materiaes? Entretanto, haverá quem negue que sejam riquezas?

(6r) Jules Rambaud, Traité élem. d'Econ. Polit., Paris, i892. Introd. $\S \mathbf{1} .^{\circ}, \mathbf{n} . \mathbf{I}$. 
exemplo: Droz, em cuja expressão «a Economia Politica, ou os principios da sciencia das riquezas, tem por fim generalisar a abastança.» (62) E ainda, L. Arnault (63), Bourdil (64), Metz-Noblat (65), Foignet (66), Bleton (67), Rubat du Merac (68), Hervé Bazin (69), Levasseur (70), Ahrendt (7 I) e muitos outros.

60. - No conceito de Houdard, «a Economica é a sciencia da riqueza», e o que seja riqueza, elle explica: "Consiste a riqueza na faculdade que tem uma pessoa de satisfazer as suas necessidades.» (72)

Philosophicamente é acceitavel, até certo ponto, tal noção de riqueza; não quadra, porém, com a idéa que, em sentido economico, se liga a esse vocabulo. Com effeito, naquella accepção, poder-se-ia considerar homem rico o philosopho, o asceta ou o selvagem, que tivessem reduzido ao minimo as suas necessidades, ou pelo desprezo do conforto, ou por espirito de sacrificio ou mortificação voluntaria, ou pelo desconhecimento dos gozos que proporciona uma civilisação adeantada; á medida que deveria ser considerado destituido de riqueza-o argentario que, dispondo embora de avultados capitaes,-não alcançasse, por meio delles, a satisfação de necessidades physicas, moraes ou intellectuaes, como sejam a saúde do corpo, a paz do espirito e as alegrias da imaginação.

(62) J. Droz, Econ. Polit., ou Principes des Richesses.

(63) L. Arnault, Cours d'Econ. Polit. Introd., pag. 39.

(64) F. Bourdil, Resumé d'un Cours d'Econ Polit. Introd. Ibi: "A Economia Politica é «o estudo das Riquezas da Humanidade.»

(65) Metz-Noblat, Cours d'Econ. Polit., cap. I.

(66) Foignet, Manuel élément. d'Econ. Polit. Introd.

67) Bleton, Man. d'Econ. Polit., cap. I. Notions préliminaires.

(68) Rubat du Mérac, Prém. Princ. d'Eion. Polit. Introd.

(69) F. Hervé-Bazin, Traité élément. d'Econ. Polit., part. I, cap. I.

(70) Levasseur, Précis d'Econ. Polit. Paris, 1888. Introd.

(7I) Ahrendr, Econ. Polit. scientifique, pag. I4 e seguintes. Elle conforma-se com a noção de J. B. SA, ampliada por STORCH.

(72) Houdard, Prem. Princ. d'Econ. Polit., part. prelim., secç. I. 
61. - Molinari não emprega, é certo, o termo riqueza, e sim, utilidades; em seu espirito, porém, está a synonimia dessas expressões, como se faz transparente deste enunciado: «A producção, a distribuição e o consumo das utilidadades - são o objecto da Economia Politica.» (73)

62. - Consoante com as opiniões que levamos enunciadas, C. Colson não está longe de annuir ás mesmas, uma $v \in Z$ que se determine com exactidão o sentido da expressão - riquezas. (74)

Estamos de accordo, tanto com esse enunciado como, principalmente, com a sua clausula restrictiva.

63.-Dutens, eximio economista e philosopho suisso, dá como objecto da Economia Politica - «o conhecimento das leis que regem a producção, a distribuição e o consumo da riqueza nas naçṍes.» (75)

Como se vê, sempre a mesma idéa e, mais ainda, com pouca diversidade de fórma.

64. -Entre os Economistas italianos, filiados á mesma escola, abstracção feita de divergencias accessorias, vamos enumerar alguns:

65. - Pantaleoni, por exemplo, dá como objecto da Economia Politica " as leis da riqueza, deduzidas da hypothese de que os homens são movidos a agir exclusivamente pelo desejo de conseguirem a maior possivel satisfação das suas necessidades mediante o menor possivel sacrificio individual.» (76)

(73) Molinari, Notions fondamentales d'Econ. Polit., cap. I, secç. I.

(74) C. Colson, Cours d'Econ. Polit., liv. I, cap. l, n. I.

(75) J. Dutens, Philosophie de l'Econ. Polit., v. I, cap. I.

(76) Maffeo Pantaleonl, Principii di Econ. pura, cap. I. 
66.-Nazzini, como os precedentes, denomina a Economia Politica - a sciencia das riquezas. Este conceito figura em ambas as suas obras de caracter geral. (77)

67. - Cossa, sem desertar da escola classica deixa, todavia, transparecer a sua preoccupação de ecclectismo harmonico, quando assirn se exprime, n'um trabalho elementar: «A Economia Politica-é a doutrina da ordem social das riquezas», e logo accrescenta: «O seu objecto é a riqueza, isto é, o complexo de bens permutaveis, por ella estudados como facto social.» (78)

Que formula feliz para quem se proponha, como este autor, a conciliar as escolas que attribuem alternativamente como objecto á sciencia economica-a ordem social, - a riqueza publica - e as permutas!

N'outra obra, amplia Cossa aquella definição e a explica nestes termos: " a doutrina da ordem social das riquezas, estudada na sua essencia, nas suas causas, nas suas leis racionaes e nas suas relações com a prosperidade publica.» (79).

A idéa de permuta logo reapparece quando, em continuação, o autor accrescenta: "A Economia Politica tem por objecto não sómente a riqueza, a saber, o complexo dos bens permutaveis e materiaes, mas a actividade humana que lhes é referente, actividade que ella estuda sob um aspecto peculiar, o do interesse geval.»

68. - Eis como a este respeito elegantemente se exprime Ciccone: «O objecto da Economia é a ri-

(77) Emm. Nazzani, Sunto di Econ. Polit. Introd. n. 2; Idem, Saggi di Econ. Polit. Introd. princ.

(78) L. Cossa, Primi Elementi di Elementi di Econ. Folit., cap. I,

(79) L. Cossa, Introduz. allo studio dell'Econ. Polit., cap. I. 
queza; nem todos os autores exprimem pelo mesmo modo este conceito; mas o conceito é o mesmo em todos os autores.» (80)

Depois de encarecer as difficuldades de uma definição verdadeiramente scientifica, justifica-se Ciccone conceituosamente da concisão da formula que adoptou, e assim se exprime:

«Se a riqueza é o sujeito generico da Economia, deve esta estudar as leis que presidem á origem della, a producção; as leis que attribuem o producto ao productor, a distribuição; as leis que regulam as trocas, a circulação; as leis que regem o uso, o consumo; e finalmente as relações que todas estas leis possam ter com o bem estar social. Quem queira comprehender todas estas cousas numa definição, entra em particularidades e faz uma descripção; quem se contente unicamente com o conceito geral da riqueza, não na separa com precisão das outras disciplinas que tambem tenham relaçđ̃es com a riqueza. Ou convém dizer que a Economia-é a sciencia que tracta das leis que governam a producção, a distribuição, a circulação e o consumo da riqueza, e das suas relações com o bem estar social; ou então, faz-se necessario restringir-se a gente a dizer-que a Economia é a Sciencia da riqueza social. Eu preferi esta ultima formula, porquê é brevissima e simplicissima, e porquê todas as definições que pela sua generalidade possam prestar-se a inexactas deducções, recebem complementos de declarações e de commentarios que lhes são additados. A minha formula tem defeitos; não conheço, porém, outra que os deixe de ter.»

69. - Seguindo as licções de Garnier et de Baudrillart, como elles considera Wolkoff a Economia Po-

(80) A. Ciccone, Principii di Econ. Polit., vol. I, noz. prelim., cap. III. 
litica - a sciencia da riqueza; não obstante, não liga este escriptor grande importancia a estas questões preliminares e se, por muito favôr, não as elimina do seu livro é pela condescendencia que tem para com os outros autores que as consideram como hors d'auvre necessario a um trabalho didactico. (8I)

Mais severa ainda, em relação a estas generalidades é a expressão de D'Eichthal, que não duvida qualifical-as de-banalidades. (82)

70. - Para Wagner, consiste o objecto da Economia Politica no estudo dos principios juridicos sobre a producção e a distribuição da riqueza. (83)

Como se vê, ha uma idéa nova nesta opinião, a saber-o caracter juridico, como essencial ao conceito das leis economicas.

Mostraremos adiante que esta noção é erronea, e se funda numa confusão entre as espheras do direito e da sciencia economica.

71. - Vejamos agóra, rapidamente, sobre este ponto o laudo de alguns economistas inglezes, além daquelles já referidos nas secçōes anteriores.

Stanley Jevons dá como ponto incontestavel que o objecto da Economia Politica é-a riqueza das nações, assim como a riqueza, em geral, o é da Economica. (84).

72.-Menos laconico, embora sem originalidade alguma, nesta particularidade mostra-se Fawcett, para

(8I) Math. Wglkoff, Précis d'Econ. Polit. rationnelle. Introd.

(82) Eug. D'Eichthal, La Formation des richesses, liv. I, cap. I.

(83) Ad. Wagner, Les Fondements de l'Econ. Polit. (versão de L. POLACH), tom. I, pag. 24.

(84) Stanley Jevons, Polit. Econ., cap. I. Introd. 
quem a Economia Politica «é a sciencia que investiga a natureza da riqueza e as leis que governam a producção, a permuta e a distribuição da riqueza.» Quanto ao que seja riqueza, elle a define «tudo o que tem um valor permutavel.» (85)

Veremos adiante a parcella de verdade contida nesta noção.

73. - Cairnes tem uma concepção ampla, mas, por isso mesmo, algum tanto vaga; pois elle inclúe na esphera da sciencia economica «tudo que se relaciona por qualquer modo com a producção, a distribuição e o consumo da riqueza.» (86)

74.-Seguindo, mais ou menos, as pegadas dos precedentes, mas procurando visivelmente conciliar as formulas de Smith e de Say, diz Nicholson que «a Economia Politica póde ser definida - a sciencia que investiga a natureza e as causas da riqueza das nações; ella se applica a descobrir as leis que affectam a producção e o consumo, a distribuição e a troca da riqueza.» (87)

75. - Os economistas hespanhóes, salvo as excepções já indicadas, seguem em geral a escola classica. Assim, Torrents y Monner, sem um cunho pessoal, já não diremos na opinião que enuncia, mas nem mesmo na fórma de que a reveste, define a Economia Politica — «a sciencia das riquezas.» (88).

76.-Vidaure y Orueta, porém, combate com muito vigor a formula de J. B. Say, contestando que

(85) FawcetT, Principles of Polit. Econ. Introd.

(86) J. E. CaIrnes, The Caracter and the logic method of Polit. Econ. Conf. I. Introd. n. 3 .

(87) J. Scheild Nicholson, Elements of Polit. Econ. Intr.

(88) Torrents y Monner, Curso de Econ. Polit. Barcellona. Introd. 
a Economia Politica seja a sciencia da producşão, distribuição e consumo. Mostra elle que o mais sabio economista póde ignorar o modo pelo qual se produzem as mercadorias; bem assim a distribuição dellas, a qual se deve effectuar naturalmente, segundo o livre arbitrio individual e não peli intervenção de qualquer poder; e, finalmente, o consumo das mercadorias: objecto de que não se occupa a sciencia economica. (89).

$\mathrm{Em}$ vista do exposto, elle conclúe que a formula, de J. B. Say deve ser substituida por esta: «A Economia Politica é a sciencia das riquezas e das suas propriedades.»E accrescenta a seguinte nota explicativa: "Sciencia é o conhecimento certo das cousas por principios fixos. E por tanto, a Economia se occupa das leis das cousas vendaveis, e bem assim das que correspondem ás propriedades das mesmas, como os preços, a utilidade e outros elementos.» (90)

Embora divergentes, por outros fundamentos, da noção de Say, devemos declarar, por lealdade, que não acceitamos a critica do economista hespanhol, a qual rezulta da accepção vulgar dos vocabulos-producção, distribuição e consumo, e não do sentido que elles devem ter na terminologia da sciencia economica.

77 - Martin y Herrera, eminente economista argentino, adopta como objecto da Economia Politica «os bens, a riqueza» e pondera que esta noção, realmente captivante pela sua singeleza, é a geralmente seguida pelos melhores economistas, entre os quaes contam-se nomes como os de Malthus, Ricardo, Stuart-Mill, MacCulloch, Baudrillart, Garnier, Courcelle-Seneuil, Ciccone, Villey e outros. (9I).

(89) Vidaurre y Urueta, Economia Politica, escola inteiramente nova, 3." cd. Bilbáo, I898. Prologo.

(9o) Vida URRe y URUeta, obr. cit. ibi: Defin. da Econ. Polit., pag. 17. (9I) Martin y Herrera, Curso de Econ. Polit., tom. I. Introd. 
78.-Merece attenção o que, ainda que deficientemente, escreve sobre este ponto Domingos Aller, com especialidade na parte referente á noção de riqueza.

«A Economia Politica, diz elle, estuda os meios de satisfazerem-se as nossas necessidades pela exploração da natureza. A somma destes meios chama-se em geral-riqueza.»

Portanto, a Economia Politica póde ser definida como «a sciencia que averigúa as relações existentes entre a producção e o consumo para augmentar a somma da riqueza publica e diminuir a somma das miserias sociaes.»

«Pela definição que acabamos de dar, prosegue o economista iberico, vemos que a riqueza-é o elemento fundamental da Economia Politica.»

Riqueza, para elle, é «a somma de utilidades que a sociedade em geral e cada homem proporcionalmente conseguem. por meio do trabalho humano auxiliado pelo trabalho da natureza.» (92)

79. - No mesmo sentido, ou antes, pela mesma conclusão opina Colmeiro, a saber, dando como objecto da sciencia economica-a investigação das leis sobre a riqueza.

Esta deducção é precedida, em sua obra, por uma erudicta exposição em que o eminente autor expõe com methodo e conceituosa critica as opiniões divergentes e as diversas formulas empregadas pelos mais notaveis economistas no intuito de assignalarem a esphera e os limites da Economia Politica. (93)

80. - Em Portugal, Oliveira Martins adoptou para titulo do seu tractado de Economia Politica-Regime

(92) Domingo E. Allér, Estudios elementales de Econ. Polit. Introd., cap. I, ns. II a I 4 .

(93) M. Colmerro, Principios de Econ. Polit., cap. IV. 
das Riquezas, e aliás, no preambulo, lembra a conveniencia de uma divisão bipartita. A' primeira elle applica o neologismo Crematistica, que não é senão, sob a forma de etymologia grega, a repetição da mesma idéa, e exprime-a sciencia abstracta que estuda as leis de formação da riqueza; á medida que, a segunda, a Economia Politica, propriamente,-é sciencia pratica, e tem por objecto os phenomenos da producção, distribuição e consumo. (94)

81.-Para não deixarmos de mencionar um provecto economista patrio, o Dr. Autran da Matta e Albuquerque,-consignaremos aqui que elle segue a rotina classica e dá como objecto da Economia Politica - «o conhecimento das leis que regulam a producção, a distribuição, a circulação e o consumo da riqueza.» (95)

82. - Como se deprehende da exposição que ahi fica e do mais que se imagina, avultado é o numero de economistas que enxergam na riqueza o objecto da Economia Politica. Não é, entretanto, uniforme o conceito que dão a essa palavra.

Tal fosse a accepção adoptada, e não estariamos longe de adherir a essa formula.

Parece-nos, todavia, que não são accessorios os pontos de divergencia que nos separam da noção dada á expressão riqueza pela generalidade dos economistas.

E' este o assumpto que agora passamos a analysar.

83. - Para Adarn Smith, são riquezas - «as cousas necessarias, uteis ou agradaveis á vida.» (96)

(94) Oliveira Martins, Regime das Riquezas. Introd. Introd.

(95) Autran da Matra e Albuquerque, Manual de Econ. Polit.

(96) Ad. Sмiтh, obr. cit., vol. I. Introd. 
Para não alongarmos demasiadamente este ligeiro estudo, limitaremos a nossa critica á doutrina do grande economista inglez em lhe oppor as seguintes perguntas: de cousas?

a) A riqueza é uma cousa ou uma accumulação

b) Ou é a propriedade de cousas ou direitos-de grande valor?

c) Ou uma relação entre os recursos e as necessidades de cada um?

d) Existe alguma objectividade nos predicados das cousas que Smith qualifica «necessarias, uteis ou agradaveis á vida»?

84.-Senior denomina riqueza «tudo que é productivo de prazer ou preventivo de pena.» (97)

Tambem não. Muitas causas produzem taes resultados sem poderem ser consideradas riqueza, a não ser em sentido figurado, improprio do estylo scientifico. Assim-uma leitura agradavel, a audição de um bello trecho de musica, a dansa, o sport, os esplendores da natureza, o somno, o descanso, a pureza do ar, a frescura da agua, o calor do sol, a benção dos pais, a amisade, o amor, etc., etc., causam prazer, ou previnem soffrimento; mas - não constituem riqueza, em sentido economico: porque não são cousas susceptiveis de compra e venda.

85.-Segundo Rozy, a palavra riqueza significa etymologicamente,-poder, e exprime, em accepção economica-a aptidão de alguem para satisfazer á sua vontade, aos seus desejos e necessidades. Levando esta noção ás suas ultimas consequencias, recusa elle

(97) Senior, Outline of the science Polit. Econ., 6." ed. Introd. 
o qualificativo de rico ao individuo possuidor de avultada fortuna, mas de ambição insaciavel, á medida que considera abastado o homem sobrio, o selvagem ou - anachoreta-que nada mais desejam além do pouco de que são possuidores. (98)

E' possivel que se recommende como philosophica tal concepção de riqueza; em Economia Poljtica, porém, não resiste á mais ligeira analyse. (99)

86. - Para Macleod, «as Economicas ou a Economia Politica, ou, como tambem é chamada, a Sciencia da Riqueza é a sciencia que tracta das leis que governam as relações das quantidades permutaveis.» ( IOO) Riqueza, ou quantidades permutaveis, ou quantidades economicas-são direitos susceptiveis de serem permutados.

$\mathrm{Ha}$, portanto, elementos economicos de diversas especies:

a) direitos sobre cousas materiaes ou corporeas ja apropriadas, como sejam terras, casas, cereaes, gado, moeda, moveis, etc., habitualmente chamadospropriedade corporea ou material:

b) direitos sobre serviços pessoaes de todas as especies, ou trabalho, usualmente chamados-propriedade immaterial; seguintes.

(98) H. Rozy, Traité élémentaire d'Econ. Polit,, cap. I, pag. $2 \mathrm{I}$ e

(99) Nem mesmo a significação etymologica autorisa o conceito de riqueza adoptado por esse economista.

De facto, segundo Rozy, riqueza deriva-se do tudesco rik ou risch, que significa-poder. Segundo LAUREnT, do allemão reich, rico. Para StapPERS, esse vocabulo vem do velbo allemão tudesco-rihhi, ou do allemão moderno reich, rico. TOUBIN propõe as seguintes etymologias: do sanscritoruk, homem rico, magnifico; do velho allemão-rihhi; do gothico-reiks; do allemão-reich; do inglez-rich. Todas estas origens são oriundas, por sua vez, do sanscrito ruc, brilho, esplendor: tendo a riqueza tirado o seu nome de um seu habitual predicado exterior.

(100) H. D. MAClEOD, The Principles of Econ. Philosophy, vol. I. Summary of definitions. 
c) finalmente, direitos realisaveis sobre cousas futuras, commumente chamados - propriedade incorporea. (IOI)

87.-Poderiamos, em conclusão, acceitar como objecto da Economia Politica - a riqueza, uma vez que sob essa denominação se comprehendesse todo o conjuncto dos elementos economicos, e por elemento economico se entendesse-toda a quantidade permutavel ou, concretamente,-tudo que é susceptivel de ser comprado $e$ vendido.

Este conceito, porém, nos proporcina uma transição natural para a exposição da doutrina que considera como objecto da Economia Politica o estudo das trocas, o que corresponde a dizer - o valor. ( $\mathrm{IO}_{2}$ )

\section{VI}

88. - A especie humana é, do reino animal, a unica que necessita da assistencia ou do concurso alheio. $\mathrm{Na}$ verdade, precisa o homem, para viver ou para o conforto physico e moral da existencia, quer da producção industrial quer dos serviços dos seus semelhantes. (103)

Ninguem produz tudo de que necessita; por isso, cada um deseja e procura os productos ou os serviços

(IOI) H. D. MACLEOD, obr. cit., vol. I.;, pag. 276.

(IO2) Nem ha, como póde parecer, assim comprehendida a noção de riqueza, o minimo antagonismo entre as fórmulas--sciencia da raqueza e sciencia do valor ou das trocas; por isso que a Economia Politica não estuda a riqueza em sua estatica, mas na sua dynamica, a saber em movimento, em evolução. Ora esta evoluçăo não se opera a não ser pela distribuição e pela circulação, ou mesmo, dada a este vocabulo a significação economicapela producção: isto corresponde a dizer-pelas permutas; por isso que produzir é fazer apparecer valor, e este não se manifesta senão com o phenomeno da troca.

(ro3) H. D. MAcLeod, Elementos de Econ. Polit. (trad. de A. DA Rocha Miranda), vol. I, n. 16. 
de outrem. Este duplo phenomeno constitúe a origem das permutas dos objectos que produzimos, ou da nossa propriedade, ou dos nossos serviços-com os produzidos pelos outros homens, a propriedade delles ou os seus serviços.

Assim, a desiderabilidade é a causa subjectiva da procura; e a permutabilidade, - a razão proxima e ob. jectiva do valor. Uma cousa procurada, sendo permutavel, - tem valor.

89. - A distribuição dos productos entre os mem bros da collectividade social póde tambem effectuar-se por intervenção da autoridade. E' esta a doutrina socialista, e a sua consagração no direito positivo, excluiria o imperio das leis da Economia Politica.

Firmados, porém, os principios da propriedade individual e da liberdade de industria e de commercio, tal distribuição se opera mediante o livre exercicio de trocas ou permutas.

90.--O predicado da permutabilidade origina o valor. O valor de uma quantidade economica é, na phrase de Macleod, a outra quantidade economica com a qual póde aquella ser trocada. Noutros termos:-o valor é a relação da egualdade entre quantidades que se permutam.

Toda propriedade póde ser objecto de troca. Esta condição determina-lhe o valor.

Ora, as leis reguladoras do valor são, exactamente, o objecto da Economia Politica.

(I04) E' manifesto que damos aqui á palavra-propriedade a sua accepção ampla e philosophica, expressiva do direito da pessoa sobre a cousa, tomado, por sua vez o vocabulo cousa em seu sentido mais amplo. Com esta noção, os serviços pessoaes são objecto de propriedade e, como taes susceptiveis de serem transferidos: estão, portanto, como vimos, na categoria dos elementos economicos. 
91. - Tudo que é permutavel, portanto, é susceptivel de valor, é-quantidade economica.

$\mathrm{Na}$ accepção ampla das expressões synonimas troca e permuta, comprehendem-se todas as especies deste genero de contracto.

Juridicamente, a permuta $€$ um contracto bilateral e synallagmatico em virtude do qual alguem dá uma cousa sua por receber outra alheia.

A permuta in genere comprehende:

a) a troca, propriamente dicta, ou a permuta in specie de objecto por objecto;

b) a compra e venda, a saber - a troca de objecto ou serviço por dinheiro, á vista ou a credito;

c) o aluguel ou arrendamento de propriedades, ou a locaşão de serviços, ou o emprestimo de capitaes, por dinheiro, outros serviços, ou a credito.

92.-As modalidades do contracto de permutas são as seguintes:

a) do ut des, ou troca de objecto (bens, productos ou dinheiro) por outros objectos.

b) do ut facias, ou troca de objecto por serviços ou obrigações;

c) facio ut des, ou troca de serviços ou obrigaç̃es por objecto (bens, productos ou dinheiro).

d) facio ut facias, ou troca de serviços ou obrigações por outros serviços ou outras obrigaç̃es.

93.-Macleod comprehende todos estes objectos e serviços sob as denominações genericas de propriedades ou direitos ou riquezas, ou mais technicamente,quantidades economicas.

Como chegou elle a esta concepção? E' o que passamos a examinar. 
94. - Sem a exacta" delimitação do seu objecto, não póde a Economia Politica offerecer os caracteres de uma sciencia.

Macleod comprehendeo a verdade deste asserto e, sectario da escola positiva, compenetrado da superioridade do methodo inductivo como processo de investigação scientifica, quiz applical-o ao estudo da Economia Politica.

Não the pareceram procedentes as objecções daquelles que contestam a adaptação deste methodo á sociologia e o reservam exclusivamente para as sciencias physicas.

O economista escossez ainda obedecia nessa tentativa a um dos processos da inducção, a saber-a analogia.

E pelo methodo analogico, conseguio discriminar no estudo da Economia Politica não sómente a concepção fundamental, a idéa basica, como concretisar esse conceito numa formula bréve, simples e clara, formula essa comprehensiva de tudo que faz parte daquella sciencia e exclusiva de tudo que lhe é extranho.

95.-Observou elle, com effeito, nas sciencias physicas :

I. Concepções fundamentaes de absoluta generalisaçâao:

2. Uma só concepçâo fundamental em cada sciencia. ( 105 )

Se a concepção fundamental não fôr geral, não será um principio, nem uma lei, nem mesmo uma regra; porquê, em sciencia, a excepção destróe a regra. $\mathrm{Na}$ verdade, se a pretendida regra soffre uma exce-

(105) Philippe Sampato, Aureliano de Campos e Mattoso Ca. mara, Exposição das doctrinas de H. D. Macleod. Lei de continuidade, pag. 9 e seguintes. 
pção-deixa de ser geval; não constitúe um todo; ao contrario, é parcial, pois o todo menos um já não é todo, é parte.

Por outro lado, se a concepção fundamental não fôr unica, não poderá ser geval. Duas concepções fundamentaes limitar-se-iam reciprocamente.

96. - Assentada a concepção fundamental-geral e unica-de uma sciencia, digamos da Economia Politica, procede-se, pela applicação da lei de continuidade, á eliminação das idéas estranhas-variaveis e accidentaes-, que ora se acham ligadas, ora não, ao conceito fundamental.

$\mathrm{E}$ assim, por este methodo, com seguro criterio obtem-se constante e invariavel a idéa basica da sciencia.

97.--Ligeiro estudo sobre o objecto das sciencias naturaes proporciona os seguintes elementos, de grande alcance analogico para o assumpto que nos occupa:

As Mathematicas - são a sciencia dos numeros ou das grandezas. Tudo que póde ser calculado ou medido é-elemento mathematico; constitúe objecto desse estudo.

A generalidade desta noção agrupa dentro da esphera das Mathematicas, as cousas as mais diversas entre si, apenas ligadas por aquella condição, a unica essencial. Exemplos: o tempo, o espaço, phenomenos materiaes, factos sociaes, o homem, bens, dinheiro, etc. A Mechanica-é a sciencia das forças. Força é tudo que produz movimento. Ha forças incorporeas, invisiveis, intangiveis, com a gravidade, a electricidade, o magnetismo, o vento, etc.; forças materiaes, como o braço humano, os animaes, a agua corrente, o va- 
pôr, etc.; forças explosivas, como a polvora, a dynamite certos alcools e gazes etc. etc.

Pois bem, todas estas forças, por mais accentuados que sejam os seus caracteres differenciaes, são -elementos mechanicos.

A Chimica-é a sciencia que estuda a combinação dos corpos. Todos os corpos-liquidos, solidos e aeriformes-, desde que contenham elementos heterogeneos combinados, são objecto do estudo da Chimica: são - elementos chimicos.

98. - Assim, tambem, a Economia Politica tem por objecto-o estudo das condições de permutabilidade (ou o valor) das cousas.

Tudo que fôr susceptivel de ser trocado é-elemento economico.

Do exposto rezulta como corollario este criterio seguro para se determinar-o que seja elemento economico: «é cousa trocavel? Póde ser vendida? E' susceptivel de valor?» No caso affirmativo,-é elemento economico: é objecto de estudo da Economia Politica.

99.-Ha, conseguintemente, grande variedade de caracteres accessorios na complexidade dos elementos economicos, cuja reunião constitúe a-riqueza social.

Elles podem ser:

a) corporeos, como terras, bemfeitorias, gado, dinheiro, moveis etc; ou incorporeos, como direitos, serviços, marcas industriaes etc.

b) pereciveis com o uso, como uma melodia musical, representação theatral, a alimentação, bebidas; ou subsistentes, apezar do uso: titulos de renda, direito autoral, o talento artistico, o vestuario, machinismos etc. 
c) duradouros, como edificações, estatuas de bronze, joias, moeda, etc.; ou de existencia limitada ou mesmo instantanea, taes como uma refeição, bebidas gazozas, o gelo, um cheque pagavel á vista etc.

d) rezultantes do trabalho, ou não, como sejam um diamante, o credito, um premio ganho em loteria etc.

e) accumulaveis, ou não, como dinheiro, serviços profissionaes, cousas que se evaporam etc.

f) uteis, ou não. Ha elementos economicos uteis, os ha inuteis, e até prejudiciaes; por isso que nada ha mais relativo do que as idéas que se ligam a taes qualificativos.

g) conformes, ou contrarios a.moral. Ha valores immoraes tambem, ou antes, cousas ou serviços contrarios á moral, mas com valor. Para que enumeral-os?

h) de existencia atual, ou futura. O credito, por exemplo, é um direito realisavel no futuro, mas susceptivel de valor actual.

100.-São, portanto, meramente accidentaes todos esses caracteres que acabamos de enumerar.

Podem elles indifferentemente concorrer ou faltar no phenomeno economico. O mesmo, entretento, não se dá em relação ao predicado da permutubilidade. Se a cousa, o serviço ou o direito - não póde ser per. mutado - não é elemento economico, o seu estudo não interessa directamente a Economia Politica, não se comprehende no dominio desta sciencia (106).

(I06) Toda a demonstração que abi fica quer sobre a lei de continuidade, quer sobre os caracteres accidentaes e o caracter essencial do elemento economico, é a fiel exposição da doutrina de MACLEod. A fórma sómente nos pertence. 
A unica origem do valor $e$, conseguintemente,a permutabilidade; porque é este o seu unico elemento invariavel, permanente e, portanto, - essencial.

101.-A vista do exposto, é licito dizer-se, com toda a propriedade, que-a Economia Politica é a sciencıa das trocas ou das permutas, que são expressões synonimas; ou, o que é equivalente, - a sciencia do valor. (107)

102. - Não está isolado Macleod neste conceito relativo ao objecto da Economia Politica; nem mesmo lhe coube a iniciativa na innovação, que ja não tem hoje este caracter. Pertence esta a Wathely, que, como vimos anteriormente, chegou a propôr outra denominação para a sciencia economica.

"O nome, diz elle, que eu houvera preferido por mais expressivo e menos susceptivel de controversia é o de Catallactica, ou Sciencia das Trocas.

O homem póde ser definido: um animal que realiza trocas; nenhum outro ser animado. possúe, segundo todas as apparencias, nem mesmo a noção da permuta ou, como se diz ordinariamente, a idéa de dar uma cousa para obter outra. E' este o unico ponto de vista sob o qual póde o homem ser contemplado na Economia Politica.

Esta opinião, prosegue o eminente arcebispo, cathedratico da Universidade de Oxford, não é essencialmente differente da de A. Smith, posto que em nossa

(107) Essa equivalencia é o corollario da noção que acima demos de valor. Como havemos de mostrar em trabalho subsequente, não nos parece fundada a distinç̧ão estabelecida por alguns economistas entre valor de troca e valor de uso. Em Economia Politica não ba senão valor de troca. O que chamam valor de uso não é mais que a utilidade; o prestimo de uma cousa: póde interessar á economia privada, não porém ao estudo da Economia Politica. 
sciencia o vocabulo riqueza deve exprimir unicamente a idéa de permutabilidade; e, por conseguinte, aquella ha de tractar das cousas tão sómente emquanto são ou podem ser objecto de troca. Considero, por isso, mais acertado definir a Economia Politica-a sciencia das trocas, do que-a sciencia da riqueza nacional.» ( I 08)

103. - Depois, tem Macleod a seu lado economistas notaveis como o inclito Bastiat e outros mais modernos, que adiante mencionaremos, convindo assignalar desde já que a phalange diariamente vai crescendo.

Bastiat, nas suas primorosas Harmonias Economicas, escreveo sobre as Trocas e o Valor dois eloquentes e conceituosos capitulos nos quaes, com o seu habitual vigor de estylo e de argumentação, demonstra o papel proeminente desses phenomenos no dominio da sciencia economica.

O primeiro destes capitulos assim começa: «A troca é a Economia Politica, é a sociedade toda inteira; pois é impossivel conceber a sociedade sem as trocas, nem as trocas sem a sociedade.

Se os homens, como os caracóes, vivessem num completo isolamento uns dos outros, se elles não trocassem os seus trabalhos e as suas idéas, se não se realissem entre elles transacções, poderia haver multidões, unidades humanas, individualidades juxta-postas; não haveria porém sociedade.»

No capitulo sobre o Valor, diz elle que «no ponto de vista economico, sociedade é troca» e accrescenta: que «a primeira creação da troca é a noção de valor.» (I 09). I 83 I.

(108) R. WAthely, Introductory Lectures on Polit. Econ. Londres, (109) Bastiat, Harmonies Economiques, caps. IV e V. 
104. - Condillac (I I O), Mac-Culloch (I I I) e, mais modernamente, Yres de Guyot (I I 2) e Dameth (I I 3 ) são accordes em denominar a Economia Politica-a sciencia do valor.

105. - Sem empregar esta formula synthetica, ou a sua equivalencia-sciencia das trocas ou sciencia do commercio, Davenport exprime, entretanto, analyticamente a mesma idéa quando attribúe como objecto da Economia Politica «a investigação do modo pelo qual os homens pensam e agem nos negocios da vida», ou a considera - "o estudo da actividade humana em relação com as cousas compradas e vendidas».

N'outro lugar da sua obra este distincto economista americano assim define a Economia Politica:- «a sciencia que tracta da actividade commercial e industrial dos homens sob o ponto de vista dos negocios $e$ dos valores.» (I I 4 )

106. - Segundo Neumann, a Economia Politica, ou antes, como elle a denomina, a Economia Social-é «a theoria dos factos e phenomenos geraes da troca, determinados pela natural tendencia do homem ao melhoramento das suas condições; o estudo das relações que as cousas economicas teem com a prosperidade geral e com o poder publico.» (I I 5)

107. - Outro autor americano, o notavel economista Perry, tambem considera a Economia Politica "a sciencia das trocas uu a sciencia do valor.» (I 6 )

(i io) Condillac, Le Commerce et le Gouvernement, etc. Amsterdam e Paris, 1776.

(I I I) MaC Culloch, Principles of Polit. Econ. Introd.

(II 2) Yves DE GuYot, La Science Economique, liv. I, cap. VI.

(I I3) H. Dameth. Introduction à l'étude de l'Econ. Pol. Prem. Séance.

(114) H. J. Davenport, Compendio di Econ. Polit., (versão para o italiano, por A. CRESPI), n. 4.

(II5) F. J. NEUMANN, Grundbegriffe der Volkswirth-schaftslehre, secç. I, $\S 3 \circ^{\circ}$, n. III.

(ii6) A. Perrx, Elements of Polit. Econ. Intr., pag. I." 
Eis como elle fundamenta a sua opinião:

Emquanto os homens provêm com os proprios esforços á satisfação das suas necessidades sem trocas, elles permanecem fóra do ambito da Economia Politica. Em taes condições, o valôr não tem determinação precisa, nem mesmo a idéa do valôr surge ao espirito; portanto, não ha sciencia do valor, abstração feita dos phenomenos da troca.

E conclúe assim:

«A unica definição que tenho por perfeitamente correcta é a do arcebispo Wathely: a sciencia das trocas.

Esta definição reúne ao redór de si os mais recentes investigadores da França, da Inglaterra e da America, onde a sciencia vai alcançando o seu maior desenvolvimento, e se ha renovado por completo o estudo da Economia Politica.» (I I.7)

108. - Entre os economistas hespanhóes dois apenas encontramos professando esta mesma doutrina, e. são Azcárate e Escudero.

Aquelle considera a troca como o objecto da sciencia economica, e nesta conformidade organisa o plano dos seus estudos. (I I 8 )

O segundo alista-se neste ponto como discipulo de Bastiat, cujas expressões faz suas.

«A palavra valor, diz elle, resume toda a sciencia economica, segundo attestam os mais eminentes economistas, um dos quaes, Bastiat, affirma que-a theoria do valor é para a Economia Politica o que a numeração é para a arithmetica.» (I I 9).

(II7) A. PERRY, obra cit., ibidem. Introd.

(i i8) Bernardo Escudero, Ensayos sobre Econ. Polit., tom. I.

(1 I9) AzCÁRAte, Estudios Economicos. Generalidades. 
109. - Vamos finalisar a presente secção additando aos illustres nomes que ahi ficam o de Pierson, ao qual anteriormente já nos referimos.

«Não é nosso proposito, escreve elle, fazer conhecidas todas as regras que se devam seguir para a satisfação do bem estar material. A missão do economista é lançar sobre essas regras a luz que póde provir do estudo das trocas.

A palavra troca 'vem aqui empregada n'uma accepção que comprehende todos os actos commerciacs. Realisa um acto commercial o operario que trabalha a salario, pois que elle dá os seus serviços por dinheiro ou mediante outra retribuição; realisa um acto commercial o proprietario que arrenda as suas terras ou aluga o seu predio, operando-se ainda neste caso uma prestação reciproca; realisa um acto commercial o capitalista que dá a juro uma parte do seu patrimonio, uma vez que proporciona a uma ou a mais pessoas instrumentos de producção e que por este serviço se faz pagar.

A Economia Politica toma como objecto de indagações estas e todas as outras especies de actos commerciaes.» (I 20)

\section{VII}

110. - Leroy-Beaulieu presta homenagem aos merecimentos de Macleod, reconhecendo nelle «uma rara penetração, uma logica poderosa e abundante erudição» e lhe dando a precedencia entre os escriptores que com elle definem a Economia Politica- a sciencia das trocas ou do valor. (l $\left.\begin{array}{lll}2 & 1\end{array}\right)$

(1 20) Prerson, Trattato di Econ. Polit., (versão para italiano, por MALAGOLI, vol. I. Introd.

(I 2 I) P. Leroy Benulieu, Traité d'Econ. Polit., vol. i..$^{\circ}$, parte I, cap. I. 
Não lhe acceita, porém, a doutrina quanto a este objecto.

111. - Ao illustre e fecundo economista francez affigura-se restricto este conceito scientifico. Para elle a Economia Politica não é sómente a sciencia das trocas, porque o seu estudo tambem comprehende factos que são diversos do phenomeno da troca, e se estende a situações nas quaes não se effectuam permutas com fito de lucro.

«A Economica, diz elle, não regula sómente o trabalho dos homens em sociedade; muitas das suas leis applicam-se do mesmo modo a uma familia isolada, e até a um homem isolado. Taes são as leis geraes do trabalho e da efficacia dos esforços humanos.

«Se consideramos uma familia que viva só, sem relaçбes com visinhos, se mesmo adoptamos a hypothese dum Robinson, muitas leis economicas, todas as que interessam a producção e o consumo, applicam-se a elle.»

112.-Se Leroy Beaulieu dá á expressão Economica um sentido generico, incompativel com a restricção rezultante do qualificativo-politica, neste caso, é procedente o seu reparo; mas o argumento deduzido não alcança a definição que adoptamos.

Entretanto, a sciencia economica ou, simplesmente, a Economia divide-se em Economia Publica (da qual é uma subdivisão a Economia Politica ou Social) e Economia Privada (que, por sua vez, subdivide-se em Economia Civil, Domestica e Pessoal ou Individual).

Não se póde, conseguintemente, imaginar Econo. mia Politica (de rolıs, cidade, sociedades) sem a coexistencia social, o commercio reciproco entre os homens.

O exemplo adduzido pelo economista francez não foi feliz. A vida e o trabalho de uma familia isolada, 
assim como o regimen observado pelo imaginario Robinson - não interessam a Economia Politica; mas tão sómente á Economia Privada.

Para que se appliquem leis de Economia Social, necessario é que exista sociedade. assim como não se podem conceber as phases da lua, sem a existencia deste satellite.

113.-Mas, Leroy-Beaulieu allega e. prova! Elle menciona, com effeito, algumas leis economicas applicaveis mesmo fóra do ambito social.

Antes de proseguir, insistamos na resposta já dada.

Taes leis são genericamente-leis economicas: mas não se caracterisam especialmente como-leis da Economia Politica, senão quando interessem ao convenio social, quando applicaveis na sociedade.

De outro modo, não serão mais do que leis, ou principios, ou normas - de economia privada: civil, domestica ou individual.

O argumento de Leroy-Beaulieu já fôra, aliás, previsto e antecipadamente respondido por Wathely, nos seguintes termos:

"Um homem que vive numa ilha deserta, como Selkirk, ou qualquer ontro personagem que se supponha tenha sido o protogonista do Robinson Crusoe, encontra-se numa situação que em rada interessa a Economia Politica, por mais que figuradamente possa chamar-se vivo, posto que possua em abundancia os meios necessarios á vida. Outra cousa succederia se a ilha estivesse habitada e os objectos fossem permutaveis.» (I 22 )

(1 22). WAthely, obr. cit. ibidem; A. BuYlla, Economia, part. I, secç. $6 .^{a}, \S 6 .^{\circ}$ 
114. - Examinemos, porém, de perto a natureza dessas leis economicas exemplificativamente indicadas por Leroy-Beaulieu, como pertencentes ao dominio da Economia Politica ou da Economica e cuja applicação, todavia, prescinde da existencia do meio social.

Começa elle por designar de modo geral «... . muitas leis economicas, todas aquellas que dizem respeito a produç̧ão e ao consumo». (I 23)

Dest'arte, são sómente excluidas, em seu espirito, as leis relativas á distribuição e á circulaşão das riquezas. Sómente estas suppõem, para a sua applicação, a convivencia de homens em sociedade.

Ora, este conceito não é verdadeiro, á luz da Economia Politica.

Evidentemente não se tracta, no presente caso, de produç̧ão agricola, industrial ou mesmo artistica. Cada uma destas se rege pela respectiva technica industrial ou artistica, e as suas leis não interessam a Economia Politica, a qual, na phrase do proprio Leroy-Beaulieu, «não ensina nem o trabalho do ferro, nem o da terra, nem o dos tecidos etc.» (i24). Tracta-se de producção economica. Ora, esta consiste em fazer apparecer valor: portanto, em vender ou expôr á venda: pois não se concebe a existencia do valor a não ser com a eventualidade da permuta, como já ficou demonstrado.

Logo, para que se dê a producçã̃o economica é indispensavel a coexistencia social.

115. -A's leis economicas sobre o consumo applica-se a mesma observação.

$\mathrm{Na}$ verdade, consumir, em sentido economico, não é--destruir algum producto, fazel-o desapparecer; mas tão sómente-compral-o.

(I23) P. Leroy Beaulieu, obr. e lug. citados.

(i 24$)$ P. Leroy Beaulieu, obr. e lug. citados. 
Fôra, de facto inapplicavel aquelle conceito aos consumidores de productos ou mercadorias de natureza permanente, ou de todas aquellas cousas que não se destróem com o uso ou, mesmo, das que não se destróem rapidamente - taes como terras, predios, moveis e semoventes, joias, objectos artisticos, vestuario etc. etc. Fôra absurdo imaginar-se que alguem procure haver taes propriedades para as destruir. Quem as adquire, entretanto, em Economia Politica denomina-se seuconsumidor.

Consumir, portanto, na technologia economica, é synonimo de comprar. Ora, para haver compra necessario é que haja venda, e tal transacção suppõe comprador e vendedor, portanto-homens convivendo em sociedade e realisando permutas.

O consumo economico, pois, não se póde operar fóra do ambito social.

116. - Leroy-Beaulieu menciona ainda, e agora expecificadamente, tres outras leis economicas applicaveis «a grande numero de negocios de caracter privado, que nenhuma relação teem com a sociedade, nem mesmo, frequentemente, com qualquer fito de lucro». ( I 25) T'aes são as leis da divisão do trabalho, da productividade dos capitaes e da fecundidade das reservas.

Estas leis, insiste o grande economista francez, «não se applicam tão sómente a homens convivendo em sociedade, mais ainda aos menages individuaes, isolados e mesmo áquelle ente hypothetico e imaginario que por vezes e durante algum tempo quiçá se encorporou n'um ente real, Robinson.»

Não é difficil a solução. Se taes leis são, e effectivamente o são, de caracter economico in genere,

(125) P. Leroy Beaulieu, obr. e lug. citados. 
que ha para se admirar em que sejam simultaneamente leis de Economia Politica e de Economia Privada? O estudo dellas, porém, não caberá na esphera da Economia Politica senão na parte em que affectarem os interesses da ordem social.

117.-Accresce que a Economia Politica não tem por objecto o estudo do organismo social sob o ponto de vista da sua estactica, a riqueza estagnada.

Esta sciencia sociologica contempla a sociedade na sua dynamica, a saber-progredindo, evolvendo. Neste conceito, a despeito de todas as divergencias que as separam, estão conformes as diversas escolas economicas.

Ora, admittida a hypothese do affastamento do gremio social-de familias e individuos, não se daria movimento progressivo na sociedade; não haveria objecto para o estudo economico. Esta hypothese, gratuita em relação á generalidade dos homens, se se realisasse a respeito de alguns individuos ou grupos familiaes, os constituiria como quantidades negativas na dynamica social.

$\mathrm{E}$ pois, a sua situação, não originando phenomenos economicos-não provocaria a applicação de leis economicas, nem pertenceria á orbita dos estudos da Economia Politica.

118. - Diz, finalmente, Leroy-Beaulieu: «Se, com o fazer-se da Economia Politica a sciencia sómente das trocas, ou a sciencia sómente do valor, póde-se alcançar a vantagem de alguma precisão apparente e de uma formula breve, exacta e clara, em compensação deixam-se escapar muitos e dos mais importantes phenomenos que affectam a producção, a repartição e o consumo dos bens. Ter-se-ia assim estranhamente 
reduzido a sciencia, sob o pretexto de lhe dar uma formula mais scientifica.» (I 26)

Poderiamos responder, em primeiro lugar, que já não seria de somenos importancia a compensação consistente em conseguir para a definição de uma sciencia-formula breve, exacta e clara.

Entretanto, não se tracta, propriamente, duma compensação, porque nada se concede $\in m$ detrimento da verdade scientifica.

A materia excluida pela formula de Macleod-é heterogenea ao estudo da Economia Politica. E isto já ficou demonstrado.

Não lucra uma sciencia com o alargar-se-lhe a esphera de estudos, incluindo-se nella elementos que não se filiam á sua idéa fundamental.

\section{VIII}

119. - Entre os impugnadores da doutrina de Macleod, quanto ao objecto da Economia Politica inscreve-se tambem o illustre Ciccone. (I 27 )

Tres são, relativamente a este ponto, as objecçoes por elle propostas:

I. $^{\mathrm{a}}$ A theoria que reduz a Economia Politica ao - estudo das permutas ou-do valor, mutila esta sciencia; porque elimina do seu dominio os pheno-

(i 26) P. Leroy Beaulieu, obr. e lug. citados.

( 127 ) O preclaro economista italiano refere-se a MACLEOD varias vezes em seus Principii di Economia, ora para lhe combater as opiniões, ora para as perfilhar, fazendo-lhe sempre as mais honrosas referencias. Tambem deu á publicidade uma interessante monographia sob o titulo-Osservazioni su'principii fondamentali del sistema economico del Macleod, editada em Napoles em 1872.

E' deste ultimo trabalho que vamos colher, para as refutar, se pudermos, as objecções de Ciccone ao conceito fundamental do nosso mestre sobre a sciencia economica. 
menos de producção, de distribuição e de consumo para circumscrevel-a unicamente aos de circulação.

$2 .^{2} \quad$ Todos os economistas são accordes em que a producção é a creação de valor; e o consumo, a destruição delle; e em que a Economia Politica estuda as leis da producção e do consumo, assim como as da distribuição e da circulação. Para que, como o faz Macleod, abandonar taes conceitos - tão simples, claros e exactos?!

3. Ainda concedendo-se que todas as cousas permutaveis sejam riqueza, a reciproca não é verdadeira; pois nem toda riqueza é cousa permutavel. Isto corresponde a dizer que se pode conceber $o$ valor independentemente do phenomeno da troca, e mesmo do predicado da permutabilidade. Logo, não é verdadeira a synonimia estabelecida por Macleod entre Sciencia das trocas e Sciencia do valor: nem, tão pouco, por conseguinte, é scientifico o seu conceito fundamental sobre o objecto da Economia Politica.

120.-Examinemos, com o cuidado que nos impõe a autoridade scientifica de Ciccone, cada uma destas objecções, e verifiquemos se, com effeito, é fundada a sua critica.

121.-Eis como vem exposta pelo seu autor a primeira das impugnações que acabamos de resumir:

"Macleod mutila a sciencia economica, porque redul-a a uma só das suas partes, a saber-á circulação, excluindo a producção, a distribuição e o consumo:

a) E elle está em contradicção comsigo mesmo, visto como escreve um excellente artigo sobre o capital, que em substancia é um factor da producção, e 
não da circulação; porque, sendo o capital «um elemento economico applicado com fito de lucro», é materia de produção, e nem pode deixar de ser assim, pela sua propria natureza assignalada pelo seu destino que é operar um accrescimo de valor.

b) A questão dos salarios é uma importantissima questão economica, que nenhum economista deixa de lado, agora principalmente que ella está na ordem do dia, em consequencia das exageradas pretenções dos socialistas. E a questão dos salarios pertence por inteira a distribuiçâo, que attribúe aos agentes da producção a parte do producto que cabe a cada um, em razão da respectiva co-participação no accrescimo do valor.

c) O luxo é um assumpto eminenternente economico, e o luxo pertence estrictamente ao consumo.» (I 28)

122. - Depois de haver explanado nestes termos a primeira parte da sua critica á doutrina de Macleod. logo em seguida e como para desencargo de consciencia, accrescenta Ciccone:

«E' verdade que Macleod considera sob um novo ponto de vista a produç̧ão e o consumo, aquella como offerta, este como procura.» (I 29)

Pois, então?!

Fôra justo, portanto, que as objecções formuladas impugnassem as theorias de Macleod quaes elle as

(128) A. Ciccone, Osservazione su'principii fondamentali del sistema economico de Macleod, pags. 6 e 7.

(I29) Traduttore tradittore! MACLEOD não diz que a produç̧ão seja simplesmente a offerta, mas-a offerta á venda (the offering for sale or exchange); e, menos ainda, elle identifica a idéa de consumo com a de procura, mas sim com a de compra (the purchase): o que offerece alguma differença. 
concebe e as expõe, e não segundo idéas alheias, por elle repudiadas.

A não ser assim, o processo empregado na critica assemelhar se-ia á construcção de um castello de cartas com o intuito de dar ao seu autor o inglorio prazer de o demolir.

123. - $E$ de facto, de onde infere Ciccone que Macleod elimina do estudo da Economia Politica os phenomenos da producção, distribuição e consumo das riquezas?

Este conceito é apenas uma erronea inducção por parte do economista italiano e, aliás, depois delle, compartilhada por outros antagonistas de Macleod.

Não tem, todavia, a minima procedencia. Denota, apenas, em quem a perfilha, superficial conhecimento das doutrinas daquelle emerito pensador.

124. - Macleod desvia-se, não ha negar, da rotina do classicismo economico, deixando de classificar as leis da Economia Politica e os phenomenos que ellas regem em leis e phenomenos de producção, circulaçãa e consumo ou-producção, distribuição, circulação e consumo. Não se segue, porém, d'ahi, que elle omitta em seus estudos os phenomenos e as leis que os outros economistas classificam sob taes denominações.

Para elle, essas divisões - tri ou quatripartita-não são scientificas; nem tão pouco é admissivel em Economia Politica o conceito commummente adoptado de producção e consumo.

Quanto á primeira parte, a divergencia é puramente methodologica; quanto á segunda, é de doutrina: não se tracta porém, em ambos os casos-de exclusăo de assumptos. 
125. - Para Macleod, como já dissemos, produzir é pôr á venda (I 30), e consumir é comprar (I 3 I). Sob uma ou outra destas categorias, podem ser classificados todos os phenomenos economicos, inclusive os de distribuiçãao e de circulaçãa.

Não é difficil a demonstração deste asserto, uma vez que se tenha presente ao espirito que produziv não é-engendrar ou crear um producto, e que consumir não é fazel-o desapparecer, destruil-o.

126. - Fallemos da distribuição e, para accompanhar Ciccone, acceitemos o exemplo do salario.

Em que e que o estudo do salario interessa a Economia Politica, a não ser da determinação do seu quantum, do seu valor, ou, na propria phrase de Ciccone, da parte que na producção deve reverter ao trabalhador?

Pois bem, no que diz respeito ao seu trabalho, o operario é um verdadeiro productor, é um productor de trabalho; pois o trabalho é o producto que elle vende. Dá-se, portanto, no caso um phenomeno de producçâo, e concomitantemente de troca; porque o trabalho é comprado por aquelle que paga o salario. Este, na hypothese, é um consumidor; pois não se concebe pro-

(130) H. D. MAcleod, The principles of Economical Phylosophy, vol. I, Summary of definitions, verbis "Produce-Producer-Production». Ibi: «Produzir-é offerecer alguma quantidade economica á venda ou á troca.-O productor é o vendedor. - A produç̧ão consiste na offerta de alguma quantidade economica á venda ou á troca.»

(I 3 I) H. D. MACLEOD, obr. e lug. citados, verbis "Consume-Consumer-Consumption.» Ibi: "Consumir é comprar (is to purchase) alguma quantidade economica.- O consumzdor é o comprador ou o freguez (the buyer, or eustomer)-Consumo, a compra de alguma quantidade economica (the purchase of any economic quantity).»

As idéas de offerta e de procura, com as quaes incautamerte CiCCoNE confunde, na technologia de MACLEOD, as de produção e de consumo, este as exprime pelos substantivos supply e demand, e as define assim (textualmente): exchange.

«Supply-is the amount of any economic quantity offered for sale or Demand-is the desire and the power to purchase any economic quantity.» 
ducção economica sem consumo, assim como não se concebe venda sem haver compra. (132)

127. - Dest'arte, a lei economica reguladora da taxa do salario é a mesma que regula o valor dos outros productos ou serviços de qualquer natureza que sejam, ou, mais genericamente, de todas as outras quantidades economicas, a saber a lei denominada $d a$ offerta e da procura.

A intervenção de outros factores sociaes de natureza a modificarem a applicação desta lei economica poderá obedecer a intuitos politicos, humanitarios ou mesmo de equidade ou de justiça; não representa, porém, phenomeno de ordem economica. O seu estudo, pois, escapa ao objecto das investigações da Economia Politica.

(132) Tão procedente é este reparo que, em direito civil e commercial, não se concebe contracto de compra simplesmente, ou simplesmente contracto de venda; mas-contracto de compra e venda. $\mathrm{O}$ mesmo se poderia dizer relativamente á producção e ao consumo. Ambas estas idéas identif. cam-se no mesmo facto. encarado porém sob aspectos differentes. Ninguem póde produzir, economicamente fallando, se não tem em vista o consumo do producto; aliás o objecto industrialmente produzido não constitúe producto em sentido economico, e a sua existencia não interessa a Economia Politica. Inversimente, não se concebe consumo a não ser de objecto produzido ou por se produzir, id est-consumo presuppondo producção.

Não pareça extranba a idéa, que figuramos, de consumo de cousa futura. Um exemplo será sufficiente para demonstrar a normalidade desta bypothese. Imagine-se um comprador de café. Que será elle senão um consumidor em relação ao productor, que lhe effectúa a venda? Pois bem, não é admissivel que este consumidor se proponha a comprar-uma safra futura? E neste caso, porque perderia elle o caracter de consumidor?

Evidentemente, quem compra para revender é tão consumidor como quem compra para seu uso pessoal. O vendedor nada tem que vêr com a applicação ulterior que o comprador destine ao producto.

Do mesmo modo, é productor-quem vende. O comprador não tem que se preoccupar se quem lhe vende o producto o produzio industrial, agricola, artistica ou scientificamente ou se, por sua vez, o houve de outrem. Para elle, é productor quem lh'o vende; porque foi este quem o poz ao seu alcance, quem o valorisou, quem o produzio mercantil ou economicamente fallando. Se este comprador propõe-se a revender o producto, e assim se constitúe intermediario, elle que foi consumidor, quando comprou, passará a ser productor desde que offereça á revenda a mesma mercadoria. 
128.-Do exposto se infere que o methodo didactico seguido por Macleod não exclúe da orbita da sciencia economica, na parte pertinente á natureza das suas pesquizas, as questões referentes ao salario e todas as outras que geralmente os economistas agrupam no capitulo por elles destinado ao estudo da distribuiçâo das riquezas.

129.-Passemos, agora, á parte da critica de Ciccone relativa a pretendida preterição, no systema de Macleod, das leis sobre o consumo.

$\mathrm{O}$ augmento e a diminuição da producção e bem assim qualquer alteração no consumo, produzem effeito immediato sobre o valor das quantidades economicas, e modificam as relações da permuta.

Como, pois, temerariamente se affirma que a escola que define a Economia Politica como a sciencia das trocas ou a sciencia do valor - exclúe do seu estudo os phenomenos da producção e do consumo das riquezas?

Fôra preciso, demonstrar-se, primeiramente, que a producção economica não faz apparecer o valor e que o augmento ou a diminuição do consumo em nada influenciam sobre as relações de compra e venda das mercadorias.

Ora, taes proposições são paradoxos.

130. - Certo, ao economista não compete investigar o modo ou os processos da producção agricola ou industrial; elle estuda esses phenomenos sob o seu ponto de vista quantitativo e qualitativo, sómente emquanto susceptiveis de influenciarem sobre as relações do valor.

Assim tambem quanto ao consumo. Nada tem o economista com o destino subsequente dado ao pro- 
ducto pelo consumidor, nem tão pouco com os moveis psychologicos que determinam a maior ou menor intensidade da procura. Estas preoccupações são extranhas á natureza das suas investigações scientificas. Isto não exprime que possa o economista deixar de assignalar taes phenomenos, quando objectivados em factos, como factores das alterações do valor.

131.-Pretendem Ciccone e, com elle e apoz elle diversos outros antagonistas de Macleod-que este economista reduz a Economia Politica ao estudo da circulação das riquezas.

Sob o ponto de vista formal, a verdade está exactamente na proporção inversa.

Com effeito, Macleod elimina da classificação tripartita de J. B. Say justamente- - a circulação. Entende elle que é inutil este membro da divisão, e que os phenomenos classificados como de circulação das riquezas ora são de produç̧ão, ora de consumo.

Assim, o commerciante, que exerce actos de mediação, que é um intermediario entre o productor e o consumidor, constitue-se por sua vez consumidor, quando compra as mercadorias para o seu commercio; e faz-se productor quando as revende a outros commerciantes ou ao publico em geral.

A classificação, portanto, em producção e consumo abrange todos os phenomenos economicos.

132. - E' já tempo de passarmos ao exame do segundo reparo opposto por Ciccone contra a classificação de Macleod.

Para que, diz elle, abandonar a antiga e classica divisão acceita pela generalidade dos economistas e já consagrada pela autoridade da sciencia? 
Comecemos por observar que esta observação é mais sentimental que scientifica.

E depois, nada é menos verdadeiro do que affirmar-se que estejam de accordo os economistas sobre esta divisão do estudo de sciencia economica.

Se quizessemos antecipar materia de outro capitulo, mostrariamos desde já quanto é temeraria esta proposição de Ciccone.

Demos, porém, que elle tenha razão. Ainda assim, tal uniformidade de vistas entre os proceres da sciencia e a consagração do passado-podem considerar-se como argumentos peremptorios?

133. - A acceitação de uma idéa pelos homens competentes não póde, nem por isso, assumir o caracter de uma camisa de malhas, que se opponha á evolução doutrinaria.

Este corollario importaria a paralysação do trabalho mental e a implicita condemnação de todo progresso scientifico.

134.-Quanto á invocação da-consagração pelo passado ou da autoridade dos economistas classicosnão passa de um inveterado sophisma já, sob outra face, desvirtuado por Laboulaye, num interessante trabalho em que, sob forma de phantasia litteraria, o publicista liberal expõe a mais conceituosa e a mais sã das doutrinas sociologicas. (I 33 )

(133) E. Laboulaye, Le Prince Caniche, cap. V. Ibi: «. .Mas, francamente, se a sabedoria, se a experiencia são o fructo da vida e do tempo, torna-se manifesto que não é aos nossos predecessores que cabem estas preciosas qualidades; é a nós vindos depois delles á scena da vida, a nós que reunimos a nossa experiencia á que os nossos avós nos legaram. Mais distanciados da infancia do mundo, somos nós os mais edosos, somos nós os antigos. Exaltar o passado para apoucar o presente é dar á mocidade e á incx. periencia os privilegios da edade madura.» 
Elle demonstra com muito espirito e verdade que, collectivamente considerados, sob o ponto de vista dos progressos da humanidade, os contemporaneos são mais velhos que os seus antepassados, e os posteros o serão mais que os homens da actualidade. Em summa, os que vivem posteriormente são os mais velhos, não somente porque vivem num tempo em que o genero humano conta mais edade, como porque lucram com os progressos já conquistados. Ao inverso estão mais proximos da infancia social os que viveram precedentemente.

Portanto, os mais sabios e os mais ajuizados devem ser os modernos, em relação aos antigos. E o argumento baseado na sabedoria destes não passa de um contrasenso.

135. - Parece excusado gastarmos mais raciocinios na refutação de tão fragil dialectica.

Passemos, pois, ao exame consciencioso da terceira objecção de Ciccone á doutrina por nós desposada sobre o objecto da Economia Politica.

136. - Eis como elle se exprime:

«Para que esta definição (sciencia do valor, sciencia das trocas) seja acceitavel, é necessario que todos as cousas que se podem trocar sejam riqueza, e que todas as cousas que são riqueza se possam trocar, comprar e vender. Ora, que todas as cousas que se podem trocar sejam riqueza, ninguem põe em duvida, se bem que não se queira dizer que sejam riqueza um golpe de espada ou um tiro de pistola trocados em duello. Ha, porém, muitas cousas que são riqueza, e todavia não se podem comprar nem vender. O capital que chamamos pessoal, moral, intellectual, o qual consiste numa capacidade adquirida por longa: 
pratica e longo estudo, o talento, a força e a aptidão especial, outhorgados pela natureza e aperfeiçoados pelo trabalho; esta especie de capital é uma riqueza preciosissima que vale mais que todas as riquezas e capitaes accumulados pelos seculos nos paizes os mais ricos e civilisados; e esta riqueza pode-se avaliar até um certo limite, mas não se pode de modo algum trocar, não se pode nem comprar, nem vender, nem dar. Macleod diz que o escravo se pode vender qual uma besta, e tem razão; mas não n'a tem quando, com o dizer que nos paizes livres os serviços do homem se podem medir em dinheiro, elle crê haver demonstrado que o capital pessoal se vende como qualquer outra riqueza. Uma cousa é o capital pessoal e outra o serviço que este capital permitte que se preste: o serviço pode-se trocar, e se troca; mas o capital não, porque está essencialmente ligado ao corpo e á alma do homem; e o homem não se troca, nem se compra, nem se vende.»

137.--Agora, a resposta.

Procedamos, porém, por partes.

Começa Ciccone concedendo que não se considerem como permutas, no sentido empregado por $\mathrm{Ma}$ cleod, a troca de golpes de sabre ou tiros de pistola n'um duello.

E' jocosa certamemente, a lembrança; não tem, todavia, outro merecimento a não ser o de uma facecia. Faz-se, pois, desnecessaria a generosidade de Ciccone.

Referindo-se á troca, em accepção economica, usou Macleod de terminologia scientifica, e não de linguagem figurada, de estylo tropologico.

Referio-se ao contracto de troca, qual o expuzemos na secção VI deste trabalho. 


\section{$-234-$}

Ora, se o duello constituisse juridicamente um contracto dessa natureza, um do ut des ou um facio ut facias, no duello a sabre ou a florete, por exemplo, seria illicita a defeza, seria uma defraudação ao direito da outra parte contractante!

$\mathrm{E}$ depois. mas para que gastar palavras?

138. - Desde que na permuta economica representa cada um dos objectos permutados a medida do valor do outro, claro se torna que-não ha troca sem revelação de valor.

Examinemos agora a reciproca, e vejamos se tem razão Ciccone quando affirma e precura demonstrar que - ha valor independentemente do phenomeno da troca ou do predicado da permutabilidade.

139. - Convém preliminarmente esclarecermos um ponto. Póde-se conceber valor sem o facto da troca, apenas com a perspectiva deste facto. Então, porém, o valor está latente, em estado potencial. Elle será nesta hypothese, méra apreciação subjectiva, que se confirmará, ou não, com a eventualidade da troca.

A desiderabilidade provoca a procura. Esta desperta a idéa do valor, que sómente o facto da troca vem revelar.

Não se concebe, portanto, valor sem a condição de permutabilidade de alguma quantidade.

140.-Ao que em sentido opposto longamente expoz Ciccone poderiamos responder em poucas palavras, apenas com um escolastico-distingo!

O capital pessoal-seja intellectual, moral, scientifico, artistico, muscular, etc. não consiste na aptidão humana para produzir, mas no exercicio dessa aptidão; 
portanto, ao contrario do que pretende Ciccone, exactamente-nos serviços, e não nas faculdades physicas ou psychicas.

Tanto é procedente este reparo que a aptidão para produzir, mas que se recusa a produzir: nenhum valor tem. $O$ jurisconsulto, o medico, o artista, o artifice-que não exercem a sua actividade, por mais idoneos que sejam, - não produzem nenhum valor. $\mathrm{E}$ se tal inercia se fizer permanente, serão taes creaturas-quantidades negativas como factores da riqueza social.

Além disso, o capital se caracterisa pela applicação, e não pela substancia. Capital inerte-são expressões antinomicas. (1 34)

141. -O capital pessoal não é, pois, o talento, a erudição dos scientistas, a imaginação ou o gosto artistico, a força, a resistencia ou a aptidão operaria, emquanto permanecem no mundo subjectivo ou não se revelam pela applicação ao trabalho; mas estas mesmas faculdades-em acção, objectivando-se em serviços-os quaes se permutam.

Os serviços de um homem livre, em todos os paizes civilisados, - são susceptiveis de compra e venda, tão bem como o serviço escravo entre os povos onde ainda perdura a instituição servil.

142. - A unica disparidade, e esta imposta pelo Direito e pela Moral e rãa pela Economia Politica, consiste em que os serviços do homem livre não se alienam perpetuamente, e os do escravo pertencem vitaliciamente ao seu senhor, e por este podem ser vendidos nas mesmas condições.

(134) A definição de capital, segundo MAcLEod, é a seguinte: «Capital é a quantidade economica applicada com fito de lucro.» Esta noção é, aliás, em fundo, compartilhada pela corrente dos economistas. 
Salvo esta differença, tanto os serviços do escravo como os do homem livre-são capitaes transferiveis, são valores que se permutam.

Não tem, portanto, fundamento, ainda nesta parte, a critica de Ciccone.

\section{IX}

143.-Adolpho A. Buylla, professor e decano da Universidade de Oviedo, tambem acommette valentemente a doutrina que considera a Economia Politica - a sciencia das trocas ou do valor. (I 35 )

Vamos expor com fidelidade as suas principaes objecções, que procuraremos refutar em poucas palavras.

144. - Não é licito, explica elle, omittir-se numa obra de Economia Politica o estudo dos phenomenos de producção e de consumo.

«Basta uma simples consideração para nos convencermos de que a troca exige necessariamente a producção e o consumo. Com effeito: será possivel dar uma cousa ou prestar um serviço para receber algo de egual natureza sem que existam ou sejam produzidos um e outro? O que se dá ou o que se recebe - seria verdadeiramente economico se não fosse applicavel á satisfacção de alguma necessidade? Troca-se o que se produzio, e se consome o que se ha trocado. Mais ainda: toda troca implica, pelo menos, dois actos de produç̧ão e se resolve em dois actos de consumo.» ( 136 )

(135) A. Buylla, Economia, cap. VI. E' esta uma obra de exposição e de critica dos systemas economicos de Neumann, KLEINWAechter, NAsse, Wagner, Mithof e Lexis. Na Introducção estuda o autor diversos conceitos sobre o objecto da Economia Politica, inclusive o de Azcarate, que, como vimos, filía-se á escola de Whately e de Macleod.

(136) A. BuxlțA, obr. e lug. citados. 
145. - Resposta:

De pleno accordo! A conclusão, porém, é nossa e não de Buylla, como se vai vêr.

Pois, se os phenomenos da producção e do consumo estão implicitamente comprehendidos nos de troca, a tal ponto que se podem discriminar em cada troca-dois actos de producção, e que tambem-ella se resolve em dois actos de consumo: o que se segue é que a formula-sciencia das trocas não exclüe o estudo das leis sobre a producção e o consumo.

Ora, esta é, exactamente, a antithese da these que estava para se provar.

146.-Prosegue Buylla:

«A troca é uma pura relação intermediaria, a qual se é um fium como troca converte-se em meio para a satisfação das necessidades (consumo). Effectivamente, a troca não é mais do que a acção de dar uma cousa por outra, ou um serviço por outro, ou uma cousa por um serviço, ou vice-versa; numa palavra: dar um valor por outro valor. Não se concebe, porém, que a isto se cinja a funcção economica, senão que transcenda ao consumo. Com effeito, de outra maneira, dar-se-ia o absurdo de haver muitos bens e muitos serviços sem applicação natural. A formula da evolução economica não é-produzir para trocar ou con. sumir para trocar, mas-produzir para consumir, $e$ trocar para consumir.) (I 37)

147.-Só se attribúe as expressões produzir e consumir as suas significaçбes technicas já anteriormente expostas, como synonimas de offerecer á venda e de comprar, estas ultimas formulas com pouca alteração

(137). A. Buylla, obr. e lug. citados. 
seriam admissiveis. Entretanto tomadas em sentido vulgar exprimem ellas um conceito erroneo em Economia Politica.

De facto, a verdade é que, em geral, a producção industrial, agricola, artistica, etc., não tem em vista senão o seu primeiro e immediato comprador, que não é o consumidor (no sentido vulgar da palavra), mas um intermediario. $O$ productor não tem que se preoccupar com o destino ulterior do seu producto; para elle, o verdadeiro consumidor é-quem lhe compra a sua producção. (I 38 )

Pode-se pois dizer no sentido que Buylla dá a estas expressões - que a producção é feita para ser vendida ou trocada, e não directamente para o seu definitivo consumo.

148.-Quanto á segunda formula de Buylla «ñ̃o se consome para se trocar, mas troca-se para se consumir», tambem não é exacta, apezar das apparencias.

E senão, vejamos.

Se consumir é synonimo de comprar, sendo comprador (ou consumidor) assim como productor (ou vendedor) termos correlatos em toda operação economica ou mercantil: segue-se que-pode-se consumir (isto é comprar) para trocar (ou revender); assim como tambem se pode trocar (dar ou receber em troca), comprar e vender para se consumir (comprar) ou se produzir (revender-se).

Afim de que ella não degenere em tautologia, ponhamos aqui ponto final a esta contestação.

(138) Vide retro: seç. VIII n. I25 e notas I3o, I31 e 132. 


\section{$\mathbf{x}$}

149.- Um economista francez, E. Worms, occupa-se tambem, com varios pontos, das doutrinas de Macleod.

Tomaremos, por agora, em consideração sómente aquellas das suas criticas referentes ao objecto da Economia Politica, e ás noções de valor e de riqueza.

\section{0. - Escreve esse autor:}

« Mas diremos nós que a Economia Politica é a sciencia do commercio, ou o que dá no mesmo, das trocas? E' o que queria já em I776, o padre de Condillac em sua obra sobre o Commercio $e$ o Go. verno. Esta opinião conta certo numero de adherentes, o que se explica, aliás, pelo importantissimo papel que cabe ao valor na analyse dos phenomenos economicos. Entre os seus mais antigos adeptos inclue-se principalmente o inglez Whately, que assim se pronunciava principalmente pela consideração de que a Economia Politica tracta sómente das cousas sob o ponto de vista da sua permutabilidade; por isso elle propunha a substituição do nome Economia Politica pelo de Catallactics (ou sciencia das trocas). Entre os modernos alistados sob a mesma bandeira, lembramonos notavelmente de Mac Leod. »(139).

151. - O estylo de Worms é assaz pesado. Convém, pois, para que seja menos ardua a leitura interromper-lhe os periodos. Isto feito, prosigamos agora:

« Mac Leod, preoccupado sobre tudo com a idéa de que uma sciencia natural-e para elle a. Eco-

(139) E. Worms, Exposé élémentaire de l'Econ. Polit., I880, Paris, cap. III «Introduction rationnelle.» 
nomia Politica pertence a esse numero (ainda que, ao mesmo tempo, moral; pois considera simultaneamente o producto e o productor) - e de que uma sciencia natural é um vasto organismo de phenomenos baseados todos sobre uma concepção geral unica (some great body of phenomena, all based upon some single general conception); de que a sciencia da mechanica, por exemplo, tracta das leis do phenomeno da força; a optica, das leis do phenomeno da luz: entende que o phenomeno a cujo estudo deve-se dedicar a Economia Politica, para se conformar com a regra de todas as sciencias naturaes, - é a troca.» (140)

152. - Exposta nestes termos a doutrina de Macleod sobre o objecto da Economia Politica, Worms faz-lhe os seguintes commentarios, dos quaes transparece pouca firmeza no seu espirito:

«E' talvez sacrificar demais ao formalismo e a uma vã uniformidade, e emparedar a sciencia num só dos seus departamentos, uma vez que ao lado da troca e anteriormente á troca, á qual preside a idéa de valor, está a producção, á qual preside a idéa de trabalho.» (I 4 I)

A esta objecção, que se tem constituido um lugar commum para os impugnadores de Macleod, já amplamente respondemos nas secções anteriores.

153. - A Worms repugna incluir na cathegoria das riquezas os productos immateriaes.

Neste ponto manifesta-se elle em profunda divergencia da opinião de Macleod e, aliás, dos mais notaveis economistas. Combate-lhe os conceitos năo sómente sob o ponto de vista racional, como tambem

(140) E. Worms, obr. e lug. citados.

(I4 I) E. Worms, obr. e lug. citados. 
quanto á sua filiação historica; e conclúe que - tanto n'um como n'outro caso os serviços pessoaes e, em geral, a propriedade immaterial - não constitúen riqueza nem, consequentemente, são objecto da Economia Politica.

154. - Eis como elle se exprime:

«. Certos autores, já nossos conhecidos pelos esforços que fázem por dar uma base não sómente philosophica e racional, mas ainda historica ao caracter que elles attribuem a Economia Politica, dizem que ella é a sciencia das trocas e que ella não comprehende sómente os productos materiaes. Citam-nos primeiramente Aristoteles, que parece ter sido quem primeiro definio a riqueza, e disse algures:

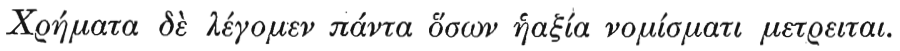

Mac Leod, que cita este trecho, triumpha facilmente traduzindo-o assim: "And we call wealth everything whose value is mesured by money»; isto é "chamamos riqueza cada uma das cousas cujo valor é medido pela moeda.» Esta versão, porém, não é bastante rigorosa, e quando feita litteralmente, dá esta formula: "chamamos riqueza todas as cousas cujo valor é rnedido pela rnoeda.» Vê-se, pois, que o corollario a tirar desta citação desfallece mais ou menos quando ella é explicada sem prevenção. . »

155. - O periodo ainda vai longe, mas façamoslhe aqui um parenthesis.

Em primeiro lugar, a traducção de Macleod não nos parece defeituosa, por isso que o adjectivo $\pi \alpha v \tau \alpha$ tem tambem o sentido partitivo de cada. (I.42)

(r42) AleXandre, Dictionnaire Grec-Français, verbo Mas. Ibi: "Пlas, $\pi \alpha \sigma \alpha, \pi \alpha v$ : tout-chaque, chacun, quelconque, qui que ce soit-tout entier, 
Todavia, esta diversidade de formas não altera nem de leve o pensamento, que é absolutamente o mesmo, quer se diga-chamam-se riqueza «todas as cousas» cujo valor se mede pelo dinheiro ou-chama-se riqueza, cada uma das cousas cujo valor se mede pelo dinheiro. Isto pela razão muito simples de que, secada cousa que se avalia em dinheiro - é riqueza, o conjuncto dellas, a saber, todas essas cousas, - é riqueza. Um todo composto de partes de uma natureza identica e homogenea não póde deixar de participar da mesma natureza dos elementos que o compõem.

Não vemos, realmente, em que a distincção feita por Worms possa aproveitar á sua doutrina restrictiva. Pois, se todas as cousas cujo valor é susceptivel de ser avaliado em dinheiro-são riqueza, segue-se que os serviços pessoaes, o trabalho humano, os direitos, em summa, toda a propriedade immaterial, desde que o seu valor possa ser avaliado em dinheiro: constitue riqueza.

Ora, que se dá essa possibilidade - os factos estão demonstrando. Logo

156.-Dar-se-á, porém, que no espirito de Worms não tenha este alcance o texto de Aristoteles, porque лavra significa-«todas as cousas», e que taes propriedades immateriaes não são cousas?

Que serão ellas, então? Pessoas?!

Não nos animamos a enxergar no texto do economista esta absurda interpretação. Entretanto, talvez seja o leitor mais perspicaz do que nós. Eis litteralmente como elle se exprime, em continuação ao trecho que já reproduzimos:

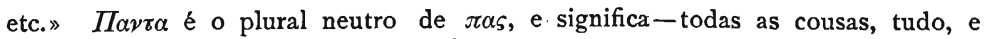
tanto póde exprimir um conjuncto de cousas, concretamente considerada cada unidade, como tambem a simples idéa da collectividade. 
".E se é incontestavel que se devam incluir na definição aristotelica os bens materiaes e mesmo as cousas incorporeas, taes como direitos, creditos, que teem um objecto material; nada está menos provado do que que ella tenha tambem tido em vista e abrangido a hypothese d'um serviço ou trabalho remunerado, do qual os homens, e não as cousas, seriam os beneficiarios.» (143)

Porque? Explica-o, ou pretende explical-o, o economista francez, com esta observação contraproducente:

157.-Diz elle: «Isto é tanto mais inverosimil (a saber que o $\pi a v \tau a$ de Aristoteles comprehenda serviços, direitos e acções) que os trabalhos industriaes e liberaes eram funcções essencialmente servis, desempenhadas em geral no serviço dos senhores e portanto gratuitas. A instituição da escravidão. levanta pois uma objecção das mais sérias contra a interpretação que combatemos.»

Ao contrario. Se o senhor do escravo era dono dos seus serviços, podia transferil-os como qualquer outra propriedade. Dessa possibilidade de alienação do trabalho escravo, e da consequente apreciação do seu valor em dinheiro, resultava para essa produç̧âo economica o caracter-de riqueza.

158. - Outro texto grego, este de Socrates, confirma eloquente e mesmo elegantemente esta noção: verá:

Debalde procura Worms desvirtual-o, como se

«Fazen tambem cabedal d'um notavel tractado que circula sob o nome de Aeschinus Socratius e se

(143) E. Worms, obr. e lug. citados. 
denomina «Eryxias», onde vem outra definição de riqueza. Os habitantes de Syracusa enviaram uma embaixada a Athenas. Socrates e os seus amigos passam um dia ao lado dos embaixadores; um amigo assignala a Socrates um dos embaixadores como o homem mais rico da Sicilia. Isto determina Socrates a dirigir as suas investigações sobre a natureza da riqueza. Eryxias declara que o homem mais rico é o que possue mais dinheiro. Socrates pergunta-que especie de dinheiro. E' a moeda dos Carthaginezes, que é de couro? Sem duvida, quem possuisse a maior quantidade desse couro em Carthago seria alli o homem mais abastado; mas estaria longe de o ser em Athenas. Em Lacedemonia circula o ferro como dinheiro; o possuidor de ferro em Lacedemonia seria, pois, muito rico, á medida que n'outra parte elle nada possuiria. Depois, com o auxilio d'uma longa argumentação, Socrates mostra que uma cousa é riqueza ou deixa de ser tal, precisamente se ella presta ou não serviços, e-se é ou não permutavel. »

159. -Outro parenthesis: Não é possivel mais explicita, mais expressiva confirmação da doutrina de Macleod e de Whately!

\section{Prosegue Worms:}

«Então, pergunta elle (Socrates)--se não ha pessoas que ganham a vida professando o ensino em seus diversos ramos? Tendo Eryxias respondido affirmativamente, Socrates pondera que todos aquelles que ensinam as sciencias ganham a vida trocando a sua instrucção por outras cousas necessarias, absolutamente como se trocam ouro e prata (I44). E é por isso que elle diz que as sciencias constituem a riqueza

(144) O grypho é nosso. 


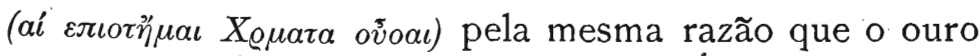
e a prata.» (145)

160.-Veja-se agora como é fraca a refutação de Worms:

«Apezar da originalidade e do sal desta conversa, não a achamos tão demonstrativa como aquelles que a trazem á argumentação. Quando Socrates disserta sobre a riqueza é muito certo que elle não pensa em resolver o problema para a solução do qual é invocada a sua autoridade, e consistente em se determinar quaes são os bens que devem fazer o objecto da Economia Politica, sciencia esta não cultivada naquelle tempo. Socrates era antes de tudo philosopho. Nessa qualidade elle inquere qual é o homem mais rico, e se applica-o que estava no seu papel de philosopho-a mostrar que um homem de espirito culto pode-se considerar (um pouco por metaphora, certamente) tão rico como aquelle cuja bolsa está bem provida.». (146)

161. - A fraqueza da impugnação nos dispensa de refutal-a, tanto mais sendo, como é, tão claro, expressivo e convincente o raciocinio do grande philosopho grego.

162. - A mesma obstinação de Worms torna-se manifesta do modo pelo qual elle commenta outros textos, invocados por Macleod, da legislação romana, em confirmação da noção ampla e scientifica por elle adoptada sobre a idéa da riqueza.

Eis, na verdade, a fragil posição na qual elle pretende se encastellar.

(146) E. WORMS, obr. e lug. citados. 
«Fossem as citações, embora, em numero maior e mais expressivas, isto é, fizessem ellas positivamente entrar na cathegoria das res, pecunia ou жепната os serviços ou trabalhos d'arte, e ainda assim nós não nos sentiriamos desarmados, e diriamos: Assim como Socrates fallou como philosopho, os autores das Pandectas e das Bacilicas fallaram como legisladores. Para. o legislador, que não tem que se preoccupar senão do que approxima contractualmente os homens, tudo o que póde ser objecto d'um contracto, d'uma troca o interessa, desperta o seu cuidado e provoca a sua regulamentação. Estes legisladores, porém, tão pouco como Socrates, não quizeram cortar uma questão extranha ao seu dominio e fincar os marcos divisorios do campo economico.» (147)

163. - Um piparote seria sufficiente para deitar por terra tão debil construcção.

Mas não vale realmente a pena perder tempo em refutar uma doutrina desde muito anachronica e hoje universalmente repudiada, - a que exclúe do circulo dos estudos economicos a propriedade immaterial.

A objecção de Worms não é a contestação sómente da doutrina de Macleod, mas de um ponto já considerado como uma conquista scientifica pelos economistas modernos.

Nesta materia, a innovação devida a Macleod não foi a theoria dos capitaes immateriaes, sobre os quaes antes delle tanto dissertaram illustres mestres da sciencia, mas toda a grandiosa perspectiva do valor do credito.

164.-Eis como a este respeito se exprime $\mathrm{Ri}$ chelot, um dos seus mais ardentes discipulos e admiradores:

(147) E. Worms, obr. e lug. citados. 
«Tudo que se póde comprar e vender entra no dominio da Economia Politica. Admittiram-se nelle a principio exclusivamente os bens materiaes; depois nelle se incluiram os bens moraes e intellectuaes, susceptiveis de serem vendidos. Não se tinha, porém, caminhado para diante; não se tomavam em conside ração senão os bens existentes no presente. Macleod foi o primeiro que trouxe ao gremio da Economia Politica uma terceira classe de objectos que legitimamente lhe pertencem.» (I48)

165.-São estas as suas palavras:

«Se incluimos na Economia Politica tudo que tem relações de troca ou de valor, tudo que se póde comprar e vender, fôra um erro evidente limitar a scien. cia aos bens que existem no presente. Todas as sociedades civilisadas offerecem propriedades de immenso valor, que não teem existencia actual, que só tẹem existencia futura, e que são objecto de troca. São esses os elementos de que tracta a theoria do valor presente dos pagamentos futuros; a saber-a theoria das rendas da terra, das annuidades, dos fundos publicos, e toda a doutrina do credito, a qual é a grande pedra angular da Economia Politica. Sob esta ultima denominação alinha-se uma consideravel massa de propriedades de valor infinitamente maior que todas as outras propriedades; e ella é inteiramente negligenciada pelos economistas. Um pagamento futuro póde ser comprado e vendido; elle tem valor actual inteiramente distincto do dinheiro no qual por fim se ha de reduzir; é um artigo de commerio tal qual como uma libra de trigo. $\mathrm{O}$ valor presente dos pagamentos aprazados, que constituem na Inglaterra artigos de doctrines.

(i48) Henri Richelot, Une révolution en Econ. Polit., cap. I. Les 
commercio, parece ser pelo menos oito vezes superior ao da moeda em circulação, e taes artigos são valores separados e distinctos desse dinheiro, do mesmo modo que as outras mercadorias. A somma das lettras de cambio e notas promissarias actualmente existentes na Gran-Bretanha sobe a $£ 500,000.000$, e o valor da moeda talvez não exceda de 70,000.000 (149): tal é a proporção. E os economistas estimam em nada esta espantosa massa de valores!» (I 5O)

166. - Se, portanto, Macleod por um lado restringe a esphera da Economia Politica excluindo della materias que lhe são estranhas, por outro, como se vê, amplia a sua orbita enfeixando nella todo este vasto dominio da theoria sobre 0 credito.

E quaes na verdade são os assumptos, cuja exclusão possa mas ou menos explicar, já não diremos justificar, nem mesmo escusar a celeuma que contra elle se levanta de haver mutilado a sciencia economica?

Que não tem fundamento a pretendida eliminação das leis sobre os phenomenos de producção, distribuição e consumo,- é ponto que já ficou sobejamente demonstrado.

A que se reduzem, pois, taes exclusões?

167-A esta interrogação assim responde $\mathrm{Ri}$ chelot, resumindo a doutrina do mestre:

«Depois de ter assignado á Economia Politica o seu objecto e os seus limites, Macleod indica o que elle exclue como assumpto extranho. A questão do imposto e a das leis dos pobres, tractadas na maior parte das obras de Economia Politica não teem rela-

(149) Isto escrevia MACLEOD em 1858. seçc. XXII.

(150) H. D. MACLEOD, Elements of Polit. Econ., liv. I, part. I, 
ção alguma com as trocas. Pertencem na realidade a uma sciencia muito mais vasta, a uma Economia Social ou Sociologia, da qual é um simples ramo a Economia Politica. Outro tanto diremos das questões relativas á herança, á emigração, ás colonias. etc. Cada uma dellas forma tambem um ramo particular da Sociologia; e embora um exacto conhecimento dos principios da Economia Politica seja indispensavel para o estudo dellas, todavia ellas não pertencem ao dominio da Economia Politica; delle apenas se approximam.» (I 5 I)

168. - Ricardo deo como titulo á principal das suas obras Principles of Political Economy and Taxation. Entendeu elle, portanto, que a theoria da taxação não faz parte da Economia Politica. A opinião contraria, seguida por J. B. Say, é compartilhada por varios economistas antigos e modernos.

Macleod, porem, circumscrevendo aos phenomenos das trocas ou ás relações do valor os limites daquella sciencia, teve de excluir delles, como acabamos de ver, - a theoria do imposto ou da taxação. (I 52 )

Embora acceitando o conceito fundamental de Macleod, não se conformam com essa consequencia os seus traductores, nossos patricios Drs. Philippe Sampaio, Aureliano de Campos e Joaquim Mattoso Camara. ( I 53)

169. - As razões em que elles se fundam para assim opinarem são antes capciosas que procedentes.

(I5I) H. Richelot, obr. e lug. citados.

(I 52) Sobre este interessante assumpto scientifico foram trocados em I873 no Diario de $S$. Paulo e no Constitucional alguns artigos de polemica entre o autor destas linhas e o seu collega e amigo (eramos ambos estudantes do $5 .^{\circ}$ anno da Faculdade de Direito) Antonio Augusto de Bulhões Jardim. Sustentava elle que-a theoria do imposto pertence á esphera da Economia Politica. Nós, porém, tinhamos então, e temos hoje, a opinião contraria.

(i53) Philippe Sampaio, aureliano de Campos e Matroso CaMARA, obr. cit., pag. 54 , nota. 


\section{Ouçamol-os :}

«Não nos parece justa a exclusão que faz o autor (Macleod) eliminando da Economia Politica as questões de taxação. Os impostos são cobrados para satisfação dos serviços publicos; são o preço pago por cada cidadão por esses serviços cujo beneficio goza; são equivalentes; ha, portanto, uma troca que é regulada pela leis da Economia Politica. Nos systemas politicos modernos, os impostos são fixados pelo povo, por meio dos representantes; acceitos pelo governo por meio da sancção, e confirmados pelo assentimento tacito dos povos.» (I 54)

170.--Responderemos em poucas palavras.

A instituição do imposto não póde ser considerada, sem o desvirtuamento da sua natureza, como acto contractual entre o contribuinte e o fisco. E' um acto de soberania, a cuja obediencia são obrigados todos os contribuintes, mesmo aquelles que não concorreram para a delegação do mandato legislativo, ou cujo voto foi vencido pelo da maioria dos eleitores. Embora sob o ponto de vista collectivo e social seja licito dizer-se, num regimem representativo, que o imposto é uma deducção da propriedade dos cidadãos, por estes consentida, para o pagamento dos serviços publicos, e portanto exprime-uma troca; todavia, convem ponderar que o direito de propriedade é individual, e não collectivo. Por conseguinte, a nação inteira, menos um proprietario divergente, não póde dispor da fazenda deste, envolvendo-a num contracto com o poder publico.

Assim, como troca de serviços, a instituição do imposto seria derogatoria dos principios fundamentaes

(154) Philippe Sampaio, Aureliano de Campos e Matroso CaMARA, obr. e lug. citados. 
quer do direito publico sobre a individualidade do dominio e a liberdade civil e commercial, quer do direito privado sobre a theoria dos contractos.

\section{Conclusão}

$\mathrm{Na}$ exposição, talvez prolixa, que acabamos de fazer nas paginas que ahi ficam, affigura-se-nos havermos demonstrado que permanece victoriosa e inexpugnavel a doutrina que reconhece como objecto da Economia Politica - o estudo das leis sobre os phenomenos das trocas ou as relações de valor das quantidades. Persistimos, por isso, em consideral-a, e a definir :

A SCIENCIA DAS TŔOCAS

ou

A SCIENCIA Do valor.

S. Paulo, 30 de Julho de 1906.

J. L. de Almeida Nogueira. 